\title{
Changes in mammary metabolism in response to the provision of an ideal amino acid profile at 2 levels of metabolizable protein supply in dairy cows: Consequences on efficiency
}

\author{
M. N. Haque, ${ }^{*} \dagger^{1}$ J. Guinard-Flament, ${ }^{*} \dagger$ P. Lamberton, ${ }^{*} \dagger$ C. Mustière, ${ }^{*} \dagger$ and S. Lemosquet ${ }^{*} \dagger^{2}$ \\ *INRA, UMR1348 Pegase, F-35590 Saint-Gilles, France \\ †Agrocampus Ouest, UMR1348 Pegase, F-35000 Rennes, France
}

\begin{abstract}
The aim of this study was to compare the modifications in mammary gland metabolism by supplying an ideal versus an imbalanced essential AA (EAA) profile at low and high metabolizable protein (or PDIE, its equivalent in the INRA feeding system). Four lactating, multiparous Holstein cows received 4 treatments composed of 2 basal diets containing 2 levels of PDIE (LP or HP) and 2 different infusions of AA mixtures $(\mathrm{AA}-$ or $\mathrm{AA}+)$ in the duodenum. The $\mathrm{AA}+$ mixture contained Lys, Met, Leu, His, Ile, Val, Phe, Arg, Trp, and Glu, whereas the AA- mixture contained Glu, Pro, and Ser. The infusion mixtures were iso-PDIE. The diet plus infusions provided 13.9 versus $15.8 \%$ of crude protein that corresponded to 102 versus $118 \mathrm{~g} /$ $\mathrm{kg}$ of dry matter of PDIE in LP and HP treatments, respectively. The treatments were designed as a $2 \times 2$ crossover design of 2 levels of PDIE supply (LP vs. HP) with 28-d periods. Infusions of AA in the duodenum $(\mathrm{AA}-\mathrm{vs} . \mathrm{AA}+)$ were superimposed to diet within each 28-d period according to $2 \times 2$ crossover designs with 14-d subperiods. Increasing the PDIE supply tended to increase milk protein yield; however, the efficiency of PDIE utilization decreased and the plasma urea concentration increased, indicating a higher catabolism of $\mathrm{AA}$. The AA + treatments increased milk protein yield and content similarly at both levels of protein supply. This was explained by an increase in the mammary uptake of all EAA except His and Trp. The mammary uptake of non-EAA (NEAA) was altered to the increase in EAA uptake so that the total AA uptake was almost equal to milk protein output on a nitrogen basis. The ratio between NEAA to total AA uptake decreased from $46 \%$ in LPAA - to $40 \%$ in LPAA +, HPAA - and
\end{abstract}

\footnotetext{
Received July 24, 2014.

Accepted March 4, 2015.

${ }^{1}$ Current address: Department of Animal Nutrition, University of Veterinary and Animal Sciences, Lahore, Pakistan.

${ }^{2}$ Corresponding author: Sophie.Lemosquet@rennes.inra.fr
}

HPAA + treatments. The PDIE efficiency tended to increase in the $\mathrm{AA}+$ versus the $\mathrm{AA}$ - treatments because the NEAA supply and the amount of NEAA not used by the mammary both decreased. Nevertheless, our $\mathrm{AA}+$ treatments seemed not to be the ideal profile: the mammary uptake-to-output ratio for Thr was higher than one in LPAA-, but it decreased to one in all the other treatments, suggesting that Thr was deficient in these treatments. Conversely, an excess of His was indicated because its uptake was similar in $\mathrm{AA}+$ and $\mathrm{AA}-$ treatments. In conclusion, balancing the EAA profile increased milk protein yield and metabolizable protein efficiency at both levels of protein supply by increasing the mammary uptake of EAA and altering the NEAA uptake, leading to less AA available for catabolism.

Key words: amino acid, metabolizable protein, mammary gland, efficiency, milk protein

\section{INTRODUCTION}

Formulating diets that can increase the efficiency of dietary nitrogen $(\mathrm{N})$ utilization is a challenging task in dairy cattle nutrition. Several dietary strategies can be combined to increase the efficiency of dietary $\mathrm{N}$ conversion to milk in lactating dairy cows. The first is to limit the dietary protein supply in excess of cow requirements for PDIE (protein digested in the small intestine supplied by RUP and by microbial protein from rumen-fermented OM, INRA, 1989) because efficiency decreases with an increasing $\mathrm{N}$ supply (Huhtanen and Hristov, 2009). The second strategy is to balance the dietary protein-to-energy ratio (Vérité and Delaby, 2000) to reduce urinary $\mathrm{N}$ excretion. In this context, a ratio of $58.8 \mathrm{~g}$ of PDIE per Mcal of $\mathrm{NE}_{\mathrm{L}}$ is reported to serve as a threshold where maximum milk protein yield can be obtained with minimal urinary $\mathrm{N}$ loss (Vérité and Delaby, 2000; INRA, 2007). The third strategy is to balance the EAA profile of dietary protein as reported for Met and Lys (Rulquin et al., 1993; Schwab, 1996; NRC, 2001). However, the fact that Met and Lys can increase milk protein yield was initially established at a high 
protein supply level; that is, at or above $65 \mathrm{~g}$ of PDIE per Mcal of $\mathrm{NE}_{\mathrm{L}}$ (Rulquin et al., 1993), where urinary $\mathrm{N}$ excretion has been shown to increase more rapidly than milk protein yield (Vérité and Delaby, 2000). In a recent study, we have shown that balancing a complete EAA profile increased milk protein yield and the efficiency of dietary $\mathrm{N}$ utilization at both a low $(<65 \mathrm{~g}$ of PDIE per Mcal of $\mathrm{NE}_{\mathrm{L}}$ ) and a high PDIE supply (Haque et al., 2012), which provided an opportunity to combine the second and third dietary strategies to mitigate $\mathrm{N}$ wastage. Consequently, this raised the problem of understanding the underlying mechanism of AA metabolism in the mammary gland (MG) that contributed to this gain in $\mathrm{N}$ efficiency.

The MG is the site where $96.5 \%$ of the milk proteins are synthesized (Cant et al., 1993) and is the largest net user of AA in the body of lactating cows (Clark et al., 1978). In terms of protein metabolism in mid-lactating dairy cows, the gross efficiency of PDIE utilization can be translated into the difference between the AA taken up by the MG for milk protein synthesis and that catabolized to produce urea (Lapierre et al., 2002). One of the possible variations in dietary $\mathrm{N}$ efficiency could be due to the partition of AA uptakes between the MG and other tissues. The MG appears to regulate the uptake of AA based on the whole-body supply of AA and the requirement for milk protein synthesis. Such studies, investigating the deficit of a single EAA, for example, His (Bequette et al., 2000) or Met (Guinard and Rulquin, 1995), showed a large modification in the mammary uptake of several AA. An increase in the mammary blood flow and the extraction rate of the deficient EAA were observed in parallel with a decrease in the extraction rate of other EAA in these studies (Guinard and Rulquin, 1995; Bequette et al., 2000). However, very few studies reported the effect of balanced diets with a complete EAA profile on milk protein synthesis (Fraser et al., 1991; Haque et al., 2012) and on mammary uptake (Bach et al., 2000; Doepel and Lapierre, 2010). In addition to the partitioning of AA uptake by the MG versus other tissues, intramammary AA metabolism could also contribute to the explanation of whole-body N-utilization efficiency. First, some EAA can stimulate milk protein synthesis or regulate mammary protein signaling pathways (Arriola Apelo et al., 2014), and second, some NEAA, for example, Pro, Ser, and Gly, are synthesized in the MG from EAA (Wohlt et al., 1977; Mepham, 1982).

Interestingly, increasing the PDIE supply has been shown to increase milk protein synthesis principally because of a higher uptake of EAA and a decreased uptake of NEAA (Lemosquet et al., 2010; Lapierre et al., 2012b). Moreover, the mammary uptake of Ile, Leu, and Val are reported to be higher than their output in milk protein, and their mammary uptake-to-output ratio increases with increasing PDIE supply (see the meta-analysis by Lapierre et al., 2012b). The $\mathrm{N}$ and carbon (C) from these EAA, which are not used directly for milk protein synthesis, could be used for NEAA synthesis (Doepel and Lapierre, 2010). This indicates that the mammary AA requirements could be different at different PDIE supply levels.

These observations emphasize the need to understand how the MG adjusts its uptake of individual AA in response to different AA profiles (balanced vs. imbalanced) at different PDIE supply levels (low vs. high). Previously, this type of experiment was conducted in early-lactating cows; however, the variation in AA profile did not greatly modify mammary AA uptake (Bach et al., 2000). The first objective of this experiment was to analyze the changes in mammary AA uptake and metabolism by supplying a balanced AA profile to the EAA profile at 2 levels of protein supply as in Haque et al. (2012). The second objective was to explain potential changes in the PDIE efficiency by analyzing the AA partition between utilization in MG and other tissues. The third objective was to review utilization of individual EAA to better define EAA requirements for dairy cows.

\section{MATERIALS AND METHODS}

\section{Cows and Surgical Preparations}

The experiment was conducted at the INRA UMR 1348 experimental farm of Méjusseaume $\left(1.71^{\circ} \mathrm{W}\right.$, $48.11^{\circ} \mathrm{N}$; Brittany, France) in the winter of 2010 to 2011 , in accordance with the National Legislation on Animal Care (certified by the French Ministry of Agriculture-Agreement No. C35-275-23). Four multiparous Holstein cows in their second lactation averaging $622 \pm$ $48 \mathrm{~kg}$ and $76 \pm 12$ DIM at the beginning of the experiment were used in this study. One week before the start of the experiment, the average daily milk yield of the cows was $36 \pm 1.9 \mathrm{~kg} / \mathrm{d}$, with a protein and fat content of $3.1 \pm 0.06 \%$ and $4.0 \pm 0.45 \%$ of milk, respectively. The cows were housed in individual tie stalls and had free access to fresh water. The cows were fitted with T-shaped duodenal cannulas 10 to $15 \mathrm{~cm}$ distal to the pylorus a year before the experiment. At $49 \pm 13$ DIM they were surgically prepared for the implantation of an ultrasonic A probe (Transonic System Inc., Ithaca, NY) on the left external pudic artery as described by Rigout et al. (2002) and 2 permanent catheters were implanted in the left carotid artery and in the left subcutaneous abdominal vein (Guinard and Rulquin, 
1994a; Raggio et al., 2006). A new protocol for analgesia and anesthesia was applied by our veterinarian for both surgeries. To tranquilize the cow, xylazine $(20 \mathrm{mg} / \mathrm{mL}$; $5 \mathrm{~mL} / 100 \mathrm{~kg}$ of BW; Rumpun 2\%, Bayer Sante, Loos, France) was injected i.m. 5 min before the induction of anesthesia. Anesthesia was then induced through an i.v. injection of ketamine $(100 \mathrm{mg} / 100 \mathrm{~mL} ; 2.5 \mathrm{~mL} / 100$ $\mathrm{kg}$ of BW; Imalgene 1000, Merical, Lyon, France). The cow was then intubated and a gaseous anesthetic, Isoflurane, was delivered $(1 \mathrm{~mL} / \mathrm{mL}$; Vetflurane, Virbac, France). During the surgery, the cow received an i.m. injection of flunixine, a nonsteroidal anti-inflammatory (Genxine: $20 \mathrm{~mL}$ at $50 \mathrm{mg} / \mathrm{mL}$; Coophavet, Ancenis, France). The cow continued to receive flunixine for 4 d (25 mL i.m.) following the surgery. No more than 4 $\mathrm{h}$ after the cow awoke from anesthesia, the analgesia protocol continued with a first i.v. injection $(1 \mathrm{~mL})$ of the morphine-like analgesic butorphanol $(10 \mathrm{mg} / \mathrm{mL}$; Buthador, Boehringer Ingelheim, Reims, France), and a second injection was administered the next morning. These injections were continued every $4 \mathrm{~h}$ if the cow showed signs of pain. Signs of pain were assessed by a multiparametric grid being completed every day by the same person from the day before surgery to $10 \mathrm{~d}$ after. In the present experiment, the 4 cows produced more than $80 \%$ of their initial milk yield $5 \mathrm{~d}$ after the surgery, and cows had recovered $98 \%$ of their initial milk production and DMI $10 \mathrm{~d}$ after the surgery.

\section{Experimental Design, Treatments, and Feeding}

The experimental design was the hierarchic scheme proposed by Guinard-Flament et al. (2007). The 4 treatments were composed of 2 basal diets (Table 1) containing 2 levels of PDIE supply combined with 2 infusions of AA mixtures in the duodenum. Diets and infusions provided either low PDIE (LP) or high PDIE (HP) level and balanced EAA $(\mathbf{A A}+)$ or imbalanced EAA $(\mathbf{A A}-)$ profile in LPAA-, LPAA + , HPAA-, and HPAA + treatments. The 2 diets were called the LP and HP diets in reference to the LP and HP treatments. These diets were supplied according to a crossover design with a 28-d period for each level. Each $28-d$ period was further divided into 2 subperiods of $14 \mathrm{~d}$, so that each cow received 1 of the $2 \mathrm{AA}$ infusions in the duodenum, superimposed on the diets according to a 2 $\times 2$ crossover design. The total duration of the experiment was $70 \mathrm{~d}$, of which $14 \mathrm{~d}$ were used to facilitate the shift between the PDIE supply levels.

The diet and infusions provided 102 versus $118 \mathrm{~g} / \mathrm{kg}$ of DM of PDIE in LP versus HP treatments, respectively. The 2 diets were iso-energetic with a $\mathrm{NE}_{\mathrm{L}}$ supply of $1.59 \mathrm{Mcal} / \mathrm{kg}$ of $\mathrm{DM}$ (the calculation accounted for the interaction between forage and concentrates ratios; INRA, 2007) to create 2 levels of PDIE per $\mathrm{NE}_{\mathrm{L}}$ (Vérité and Delaby, 2000) in the LP and HP treatments. The $\mathrm{AA}$ mixtures (AA+; AA vs. AA-; $\mathrm{AA}$ and urea) were iso-PDIE and iso-N (Table 2) and provided $218 \mathrm{~g} / \mathrm{d}$ of AA in the duodenum, accounting for 11.4 and $9.4 \%$ of the total PDIE (diet and infusions) in the LP versus HP treatments, respectively (Table 3 ). The AA+ mixtures were formulated in such a way that the LPAA+ and HPAA + treatments (diets and infusions) provided an EAA profile in percentage of PDIE that was close to the ideal profile proposed by Rulquin et al. (2007) and Doepel et al. (2004).

The LP and HP diets were composed of corn silage, soybean meal, energy concentrate, urea, mineral and vitamin premix, and bicarbonate (Table 1). The LP and HP diets (Table 1) provided 13.0 and $14.8 \%$ of CP, respectively, corresponding to 86 versus $103 \mathrm{~g} / \mathrm{kg}$ of

Table 1. Ingredient, chemical, and nutrient compositions of the 2 diets to create low-protein (LP) and high-protein (HP) treatments

\begin{tabular}{|c|c|c|}
\hline Item & LP diet & $\mathrm{HP}$ diet \\
\hline DM, $\%$ & 54 & 54 \\
\hline \multicolumn{3}{|l|}{ Ingredient, $\%$ of DM } \\
\hline Corn silage & 62.9 & 63.3 \\
\hline Soybean meal & - & 6.2 \\
\hline Ground dehydrated wheat grains ${ }^{1}$ & 18.4 & 14.9 \\
\hline Ground corn ${ }^{1}$ & 7.3 & 5.9 \\
\hline Potato pulp ${ }^{1}$ & 7.3 & 5.9 \\
\hline Saponified palm oil ${ }^{1}$ & 0.3 & 0.3 \\
\hline Sugar molasses $^{1}$ & 1 & 0.8 \\
\hline Salt $^{1}$ & 0.4 & 0.3 \\
\hline Urea & 0.4 & 0.4 \\
\hline Bicarbonate & 0.7 & 0.7 \\
\hline Minerals and vitamins ${ }^{2}$ & 1.3 & 1.3 \\
\hline \multicolumn{3}{|l|}{ Nutrient composition, per $\mathrm{kg}$ of DM } \\
\hline OM, g & 933 & 932 \\
\hline $\mathrm{CP}, \mathrm{g}$ & 130 & 148 \\
\hline Ether extract, $\mathrm{g}$ & 41 & 39 \\
\hline $\mathrm{ADF}, \mathrm{g}$ & 176 & 174 \\
\hline $\mathrm{NDF}, \mathrm{g}$ & 346 & 339 \\
\hline ADL, g & 19 & 18 \\
\hline Crude cellulose, $\mathrm{g}$ & 150 & 149 \\
\hline Starch, g & 290 & 274 \\
\hline \multicolumn{3}{|l|}{ Nutritive values, per $\mathrm{kg}$ of DM } \\
\hline $\mathrm{PDIN}^{3} \mathrm{~g}$ & 86 & 103 \\
\hline $\mathrm{PDIE}^{4} \mathrm{~g}$ & 93 & 108 \\
\hline $\mathrm{NE}_{\mathrm{L}},{ }^{5} \mathrm{Mcal}$ & 1.59 & 1.58 \\
\hline
\end{tabular}

${ }^{1}$ Pelleted in a concentrate given at 34.7 and $28.1 \%$ of DM intake in LP and HP diets, respectively.

${ }^{2}$ Calcium carbonate $(52 \%)$, dicalcium phosphate $(23 \%)$, calcium phosphate and magnesium phosphate $(10 \%)$, sugarcane molasses $(9 \%)$, magnesium oxide and other additives (6\%), 600,000 IU of vitamin A, and 80,000 IU of vitamin $\mathrm{D}_{3}$.

${ }^{3} \mathrm{PDIN}=$ protein digested in the small intestine supplied by RUP and by microbial protein from rumen-degraded dietary N (INRA, 1989).

${ }^{4} \mathrm{PDIE}=$ protein digested in the small intestine supplied by RUP and by microbial protein from rumen-fermented OM (INRA, 1989).

${ }^{5} \mathrm{NE}_{\mathrm{L}}$ corrected for concentrate-roughages interaction (INRA, 2007). 
Table 2. Amount of AA (g/d) infused into the duodenum of cows for each treatment ${ }^{1}$

\begin{tabular}{lcccc}
\hline $\begin{array}{l}\text { Item, } \\
\text { g/d }\end{array}$ & LPAA - & LPAA + & HPAA - & HPAA + \\
\hline Arg & & 14.6 & & 9.3 \\
His & & 24.3 & & 26.0 \\
Ile & & 12.5 & & 13.3 \\
Leu & & 27.2 & & 29.2 \\
Lys & & 31.1 & & 31.9 \\
Met & & 14.8 & & 19.6 \\
Phe & & 32.7 & & 38.2 \\
Trp & & 6.2 & & 6.3 \\
Val & 124 & 35.2 & 124 & 23.6 \\
Glu & 58.0 & & 58.0 & \\
Pro & 36.0 & & 36.0 & \\
Ser & 218 & 218 & 218 & 218 \\
Sum & 18.5 & & 16.9 & \\
Urea & 32.1 & 32.2 & 31.4 & 31.4 \\
N supply & & & \\
\hline
\end{tabular}

${ }^{1}$ LPAA $-=$ low-protein diet + duodenal infusions of Glu, Pro, Ser, and urea; LPAA $+=$ low-protein diet + duodenal infusions of Lys, Met, Leu, His, Ile, Val, Phe, Arg, Glu, and Trp; HPAA- = high-protein diet + duodenal infusions of Glu, Pro, Ser, and urea; HPAA $+=$ highprotein diet + duodenal infusions of Lys, Met, Leu, His, Ile, Val, Phe, Arg, Glu, and Trp.
DM of protein digested in the small intestine supplied by RUP and by microbial protein from rumen-degraded dietary N (INRA, 1989) and 93 versus $108 \mathrm{~g} / \mathrm{kg}$ DM of PDIE. The diets were offered in a restricted amount per period per cow to cover the $\mathrm{NE}_{\mathrm{L}}$ requirements (INRA, 2007 ) in the middle of the experiment. To predict the quantity of the diet offered, a lactation persistence of $98 \%$ on milk yield of the reference week ( $7 \mathrm{~d}$ before the start of experiment) was applied, assuming that milk protein and fat content would remain unchanged. Corn silage was offered 3 times per day (25\% at 0715 h, $25 \%$ at $1315 \mathrm{~h}$, and $50 \%$ at $1915 \mathrm{~h}$ ). However, to maintain a steady state during the blood sampling days, the silage was offered 5 times per day $50 \%$ of the corn silage was divided in 4 equal parts and distributed at 0715 , 1015,1315 , and $1615 \mathrm{~h}$, whereas the remaining $50 \%$ was distributed at $1915 \mathrm{~h}$ ) as described by Raggio et al. (2006). The concentrate and soybean meal were offered every $3 \mathrm{~h}$ starting from $0715 \mathrm{~h}$. In the first $9 \mathrm{~d}$ of each period, cows were milked twice a day at 0630 and 1730 $\mathrm{h}$, whereas in the last $5 \mathrm{~d}$, milking was performed at 0630 and $1830 \mathrm{~h}$ and the udder halves of each cow were milked separately.

Table 3. Estimated intestinal AA flow as predicted by AADI ${ }^{1}$ system from the basal diet at observed mean DMI, and total AA flow from basal diet and infusions expressed as percentage of metabolizable protein $\left(\%\right.$ of $\left.\mathrm{PDIE}^{2}\right)$ and grams per day

\begin{tabular}{|c|c|c|c|c|c|c|c|c|c|c|}
\hline Item & \multicolumn{2}{|c|}{ Diet, $\%$ of PDIE } & \multicolumn{4}{|c|}{ Treatment, ${ }^{3} \%$ of PDIE } & \multicolumn{4}{|c|}{ Treatment, $\mathrm{g} / \mathrm{d}$} \\
\hline \multicolumn{11}{|l|}{ AADI } \\
\hline HisDI & 2.1 & 2.1 & 1.9 & 3.0 & 2.0 & 3.0 & 43 & 67 & 52 & 78 \\
\hline IleDI & 5.1 & 5.1 & 4.6 & 5.2 & 4.7 & 5.2 & 106 & 117 & 124 & 137 \\
\hline LeuDI & 8.7 & 8.6 & 7.8 & 9.0 & 7.9 & 9.0 & 179 & 204 & 208 & 237 \\
\hline PheDI & 5.0 & 5.1 & 4.6 & 6.0 & 4.7 & 6.1 & 104 & 136 & 123 & 161 \\
\hline ThrDI & 5.0 & 4.9 & 4.5 & 4.5 & 4.5 & 4.5 & 103 & 102 & 120 & 119 \\
\hline ValDI & 5.7 & 5.6 & 5.1 & 6.0 & 5.1 & 6.0 & 117 & 136 & 135 & 159 \\
\hline AlaDI & 6.6 & 6.5 & 6.0 & 6.0 & 5.9 & 5.9 & 136 & 135 & 157 & 157 \\
\hline AspDI & 10.1 & 10.4 & 9.1 & 9.1 & 9.5 & 9.5 & 208 & 206 & 252 & 251 \\
\hline GluDI & 15.9 & 15.8 & 19.8 & 15.9 & 19.2 & 15.3 & 451 & 360 & 507 & 402 \\
\hline GlyDI & 5.9 & 5.8 & 5.3 & 5.3 & 5.3 & 5.3 & 121 & 120 & 140 & 139 \\
\hline TAADI $^{6}$ & & & 97 & 97 & 97 & 97 & 2,214 & 2,192 & 2,561 & 2,548 \\
\hline PDIE (diet + infusion) & & & & & & & 2,280 & 2,263 & 2,638 & 2,634 \\
\hline
\end{tabular}

${ }^{1}$ AADI $=$ AA digestible in the small intestine (DI; Rulquin et al., 1998, 2001; INRA, 2007).

${ }^{2} \mathrm{PDIE}=$ protein digested in the small intestine supplied by RUP and by microbial protein from rumen-fermented OM (INRA, 1989).

${ }^{3}$ LPAA $-=$ low-protein diet (LP) + duodenal infusions of Glu, Pro, Ser, and urea; LPAA + = LP + duodenal infusions of Lys, Met, Leu, His, Ile, Val, Phe, Arg, Glu, and Trp; HPAA - = high-protein diet (HP) + duodenal infusions of Glu, Pro, Ser, and urea; HPAA+ = HP + duodenal infusions of Lys, Met, Leu, His, Ile, Val, Phe, Arg, Glu, and Trp.

${ }^{4}$ EAADI = sum of ArgDI, HisDI, IleDI, LeuDI, LysDI, MetDI, PheDI, ThrDI, and ValDI.

${ }^{5}$ NEAADI $=$ sum of AlaDI, AspDI (Asp+Asn), GluDI (Glu+Gln), GlyDI, ProDI, SerDI, TyrDI.

${ }^{6}$ TAADI $=$ the sum of the AADI, which represented $97 \%$ of PDIE supply by diet plus infusion. 
The AA infusions (Table 2) were as follows: (1) a mixture that contained Arg, His, Ile, Leu, Lys, Met, Phe, Trp, and Val (AA+) and (2) a mixture that contained Glu, Pro, and Ser, along with urea (AA-). The formulations of the $\mathrm{AA}+$ mixture in the $\mathrm{LP}$ and $\mathrm{HP}$ treatments (diet and infusions) were targeted to provide the ideal EAA profile (in percentage of PDIE) proposed by Rulquin et al. (2007) for LysDI (7.3\%; DI = digestible in the small intestine), MetDI (2.5\%), HisDI (3\%), LeuDI (8.9\%), and ThrDI (4.0\%), whereas ArgDI (4.8\%), IleDI $(5.3 \%)$, and ValDI $(6.3 \%)$ were targeted according to Doepel et al. (2004). The concentration of Phe $(6.1 \%)$ was increased to secure the supply of TyrDI in accordance with Doepel and Lapierre (2010). As the concentration of Trp in the INRA system (2007) was not known, the quantity of Trp for duodenal infusion was calculated by applying a Trp:Lys ratio $(0.18)$ in milk proteins (Swaisgood, 1995) to the value of $7.3 \%$ LysDI. To make the 4 infusions iso-PDIE, NEAA (Glu, Pro, and Ser) were infused in the LPAA - and HPAA - treatments. We chose these 3 NEAA because their intestinal concentrations provided by the diets were lower than their concentrations in milk protein (with GluDI for Glu + Gln), whereas the intestinal concentrations of the other NEAA were higher than their concentrations in milk protein (Swaisgood, 1995). The intestinal concentration (diet and infusions) of GluDI $(19.5 \pm 0.4 \%)$, ProDI $(7.1 \pm 0.3 \%)$, and SerDI $(5.9 \pm 0.1 \%)$ was set not to exceed their concentration in milk protein (Swaisgood, 1995: Glu + Gln $=23 \%$ of true protein, Pro $=10.8 \%$ and Ser $=6.8 \%)$. To make the 4 infusions iso-PDIE (218 g/d of AA), Glu was also included in $\mathrm{AA}+$ infusions. To make the $4 \mathrm{AA}$ infusions iso- $\mathrm{N}$, urea was infused in the duodenum because urea is known to be absorbed with water in the intestine of ruminants (Kijora et al., 1992). Urea was infused at a rate of $18.5 \pm 1.8$ and $16.9 \pm 1.1 \mathrm{~g} / \mathrm{d}$ in $\mathrm{LPAA}-$ and HPAA-, respectively, so that each infusion supplied $32 \pm 0.4 \mathrm{~g} / \mathrm{d}$ of $\mathrm{N}$ (Table 2). Free AA, that is, L-Lys $\mathrm{HCl}$, L-His $\mathrm{HCl} \mathrm{H}_{2} \mathrm{O}$, L-Leu, L-Phe, L-Ile, L-Val, L-Trp, L-Arg, L-GluNa $\mathrm{H}_{2} \mathrm{O}$, L-Pro, and L-Ser were obtained from Ajinomoto Co. Inc. (Tokyo, Japan). We used DLMet obtained from Adisseo (Rhodimet, Commentry, France) knowing that almost all D-Met is converted to L-Met in some species (Hasegawa et al. 2005) and that more than $75 \%$ D-Met was recently reported to be converted to L-Met in dairy cows (Lapierre et al., 2012a).

The AA were dissolved in $10 \mathrm{~L}$ of tap water daily and continuously infused $(24 \mathrm{~h})$ in the duodenum using a peristaltic pump (Gilson, Villers de bel, France). The first $2 \mathrm{~d}$ of each treatment served as a transition for infusions where the cows received $33 \%$ of infusion on the first day and $66 \%$ of the daily infusion on the second day as described by Raggio et al. (2006).

\section{Measurements, Sample Collection, and Preparation}

The quantity of the ration offered and orts (when present) were weighed daily. Samples of the corn silage and refusals were collected on a daily basis and samples of concentrates were collected on a weekly basis to determine the DM content, by drying in a forced-air oven at $80^{\circ} \mathrm{C}$ for $48 \mathrm{~h}$. After determination of the DM content of the corn silage, the quantity of corn silage offered was adjusted every day to ensure the same delivery of DM on each experimental day. The samples were ground to pass through a $0.5-\mathrm{mm}$ screen and were subjected to analysis of the AA content by HPLC (Alliance System, Waters Corp., Guyancourt, France) after protein hydrolysis with $6 \mathrm{~N} \mathrm{HCl}$ at $110^{\circ} \mathrm{C}$ for $23 \mathrm{~h}$ under reflux. The AA contents were measured using cation exchange chromatography after acid hydrolysis for 24 h (Directive 98/64/CE, 3/09/99-Norme NF EN ISO 13903; ISO, 2005). Analysis of Met and Cys were performed after the initial oxidation of the samples with performic acid. Phenylalanine was analyzed without oxidation, whereas Trp was analyzed after hydrolysis in $4 \mathrm{M}$ barium hydroxide at $110^{\circ} \mathrm{C}$ for $16 \mathrm{~h}$ (AFNOR XPV 18-114; AFNOR, 1998). The values for AA digested in the small intestine from these measurements were calculated (Table 3 ) as proposed by Rulquin et al. (1998, 2001).

Milk production was recorded at each milking, and milk samples from the left udder were assayed via infrared analysis using a Milkoscan 605 (Foss Electric, Hillerød, Denmark) to determine protein, fat, and lactose content at each milking. On the d 13 of each subperiod, milk samples from the left udder were collected from the 0630 and $1830 \mathrm{~h}$ milking to determine total N, NPN, and noncasein $\mathrm{N}$ using the Kjeldahl method. To analyze the concentration of milk urea, $20 \mathrm{~mL}$ of milk was filtered using Vivaspin 20 (Sartorius, VWR, Fontenay sous Bois, France) and centrifuged $(1,800 \times g$ for 45 min at $35^{\circ} \mathrm{C}$ ). The supernatant was then analyzed with a multiparameter analyzer (KONE Instruments Corporation, Espoo, Finland) using colorimetric enzymatic reaction [urease and glutamate dehydrogenase (Urea coffret; Thermo Fisher Scientific, Illkirch, France)]. Furthermore, the AA composition of the milk protein from the $1830 \mathrm{~h}$ milking was analyzed using a HPLC (Alliance System, Waters Corp.) following protein hydrolysis with $6 \mathrm{~N} \mathrm{HCl}(23$ or $24 \mathrm{~h})$. The sulfur AA, that is, Met and Cys were separately liberated by oxidation using performic acid before the protein hydrolysis.

On d 13 of each subperiod, starting from $0700 \mathrm{~h}$ (after the morning milking), 6 blood samples (1 sample every $2 \mathrm{~h}$ ) were collected from each cow simultaneously from the left carotid artery and the left subcutaneous abdominal vein in heparinized syringes (S-Monovette, 
7.5 mL; Sarstedt, Nümbrecht, Germany, 16 IU/100 mL of heparin) and were immediately centrifuged $(2,000 \times$ $g$ for $15 \mathrm{~min}$ at $4^{\circ} \mathrm{C}$ ). Plasma was aliquoted and stored at $-80^{\circ} \mathrm{C}$ for $\mathrm{AA}$ analyses and at $-20^{\circ} \mathrm{C}$ for the analyses of urea. Plasma AA, peptides, and AA metabolite concentration were determined using a UPLC/MS (Waters Acquity Ultra Performance LC system, Waters Corp.) as previously described (Haque et al., 2012). Plasma samples for urea were analyzed with a multiparameter analyzer (KONE Instruments Corporation) using a colorimetric enzymatic reaction (urease and glutamate dehydrogenase; Urée UV Cinétique, KONE Diagnostics, Evry, France).

\section{Calculations}

The gross efficiency of PDIE for milk protein synthesis was calculated by dividing the milk protein yield by the PDIE intake of the diet and infusion. The metabolic efficiency of PDIE utilization was calculated according to the method of INRA (2007):

$$
\text { PDIE efficiency }=\frac{\text { milk protein yield }}{\text { PDIE intake }- \text { PDIE maintenance }} \text {. }
$$

The PDIE for maintenance was calculated as $3.25 \times$ $\mathrm{BW}^{0.75}$ as defined by INRA (2007). Nitrogen efficiency was calculated by dividing the $\mathrm{N}$ secreted in milk by the total $\mathrm{N}$ intake (including the diet and duodenal infusions of $\mathrm{AA}$ and urea). The $\mathrm{NE}_{\mathrm{L}}$ balance was calculated by subtracting $\mathrm{NE}_{\mathrm{L}}$ intake with $\mathrm{NE}_{\mathrm{L}}$ requirement as defined by INRA (2007).

Mammary plasma flow was calculated using the Fick principle on Phe + Tyr as described in Raggio et al. (2006) because mammary $\mathrm{C}$ and $\mathrm{N}$ balances (calculated as described by Raggio et al., 2006, and Lemosquet et al., 2009) obtained through ultrasonic probes were not validated for one cow. In this cow, when plasma flow was measured with the A probe, the mammary C uptake represented $123 \%$ of the milk $\mathrm{C}$ plus the blood $\mathrm{CO}_{2}$ output. Moreover, the mammary $\mathrm{N}$ uptake of this cow represented $143 \%$ of its output in milk; and the Phe + Tyr mammary uptake to milk output $(\mathbf{U}: \mathbf{O})$ ratio was greater than one (1.58). For the remaining 3 cows, the mammary $\mathrm{C}$ and $\mathrm{N}$ balances calculated with the probe blood flow were not significantly different from zero, and the mammary $\mathrm{U}: \mathrm{O}$ ratio for Phe + Tyr (calculated with the probe) was not significantly different from 1.0 (0.90, 1.06, and 1.09 for cows 2, 3, and 4, respectively) indicating that the Fick principle could be applied in this experiment. Indeed the mammary total AA (TAA) U:O on a $\mathrm{N}$ basis was almost at one for the 4 cows and for the 4 treatments (see Results section) when plasma flow was estimated using the Fick principle.

The mammary net uptake and the $\mathrm{U}: \mathrm{O}$ ratio of AA were calculated on the left udder as described by Raggio et al. (2006). To obtain information on the capacity of the mammary net transport system, the mammary clearance $(\mathrm{Km}, \mathrm{L} / \mathrm{h})$ of nutrients was calculated using the model of Hanigan et al. (1998b):

$$
\operatorname{Km}(\mathrm{L} / \mathrm{h})=\frac{([A]-[V]) \times \text { plasma flow }}{[V]}
$$

The clearance $(\mathrm{Km})$ corresponds to the ability of the udder to clear AA from the plasma per unit of time, and $A$ and $V$ correspond to arterial and venous concentrations of AA, respectively.

Milk AA output was calculated using the milk protein yield of the left udder (evening milking on d 13) with a 3.5\% correction for blood-borne proteins, and the AA composition of milk as analyzed for this study (mg of AA/g) of true protein: Ala (34.6), Asn + Asp (76.7), Arg (36.6), Cys (8.2), Glu + Gln (219.5), Gly (19.8), His (28.4), Ile (51.9), Leu (102.3), Lys (87.3), Met (26.2), Phe (50.7), Pro (106.8), Ser (50.9), Thr (43.2), Tyr (54.4), Val (65.3) or calculated for Trp (15.0) using Swaisgood (1995). To calculate the sums for the AA on a $\mathrm{N}$ basis, the proportions of Asp:Asn and Glu:Gln in Swaisgood (1995) were used.

To analyze the partition of intestinal AA (AADI) between mammary uptake and other tissues on an $\mathrm{N}$ basis, the whole intestinal AA-N supply was calculated using individual AADI in grams per day in Table 3, and whole-udder uptake of AA-N was calculated on the last $5 \mathrm{~d}$ of the experiment considering the $18 \mathrm{AA}$ of intestinal AADI with

whole udder uptake

$$
=\text { left udder uptake } \times \frac{\text { milk protein yield }(\text { mean of } 5 \mathrm{~d})}{\text { left udder milk protein yield }(12 \mathrm{~h})} \text {. }
$$

\section{Statistics}

The data were analyzed using the MIXED procedure of SAS (SAS Institute Inc., 2004) according to the following statistical model (Guinard-Flament et al., 2007; Haque et al., 2012):

$$
\begin{gathered}
Y_{i j k l m}=\mu+\operatorname{cow}_{i}+\operatorname{period}_{j}+\operatorname{wk}_{k}\left(\operatorname{period}_{j}\right)+\operatorname{PDIE}_{l} \\
+\mathrm{AA}_{m}+\operatorname{PDIE}_{l} \times \mathrm{wk}_{k}\left(\operatorname{period}_{j}\right) \\
+\mathrm{PDIE}_{l} \times \mathrm{AA}_{m}+\varepsilon_{i j k l m}
\end{gathered}
$$


where $\mu$ is the grand mean, $\varepsilon$ is the random error, period represents the 4 -wk period, wk(period) represents the 2-wk subperiod within the 4 -wk periods, PDIE represents the level of metabolizable protein supplied, and AA represents the AA profile. The error term used for testing treatment effects was defined by the interaction cow $\times$ period $\times$ PDIE with a random effect. This model conferred considerable accuracy in the statistical test for the AA profile effect and limited the power of the protein-level supply because of the small number of degrees of freedom and the largest residual error used (Steel and Torrie, 1980). The results are expressed as least squares means with the highest standard error of the means. There were no missing data $(\mathrm{n}=16)$ except for milk urea $(\mathrm{n}=15)$. We verified that the distribution of residues was homogeneous. The significance level was set to $P \leq 0.05$, and the tendency was set to $0.05<P$ $\leq 0.10$. When the PDIE $\times$ AA interaction was significant, Student's $t$-tests were used to compare LPAA+ to LPAA - and HPAA + to HPAA -, respectively.

\section{RESULTS}

\section{DMI, Milk Production, and Milk Composition}

Dry matter intake was not affected by the treatments (Table 4, mean $5 \mathrm{~d}$ ). As expected, the PDIE/NE $\mathrm{N}_{\mathrm{L}}$ increased by $18 \%$ in the HP versus LP treatments, whereas it remained unchanged between the $\mathrm{AA}-$ and $\mathrm{AA}+$ treatments. The increased PDIE supply had no effect on milk composition or milk component yield except for milk protein yield, which tended to increase by $6.2 \%$ compared with the LP treatments (contrast PDIE: $P=$ 0.09). Nitrogen efficiency tended to decrease by increasing the PDIE supply $(P=0.08)$. The gross and metabolic PDIE efficiencies of utilization for milk protein in the HP treatments were decreased by 8.6 and $11 \%$, respectively, compared with LP treatments $(P<0.05)$. Moreover, the metabolic PDIE efficiency observed in the LP treatments was close to the fixed metabolic efficiencies (0.64) used to define the PDIE requirements for milk protein production in INRA (2007). The $\mathrm{NE}_{\mathrm{L}}$ balance decreased in response to the high PDIE supply level $(P=0.04)$. The AA+ treatments increased milk yield by $1.8 \%$ compared with the AA - treatments (contrast AA: $P=0.03$ ); however, the responses tended to be inconsistent across PDIE supply levels (interaction PDIE $\times$ AA: $P=0.06$ ). Milk yield was higher in the HPAA + compared with HPAA - treatment $(P$ $<0.05)$, whereas it was not affected in the LPAA+ versus LPAA - treatment. The AA+ treatments tended to increase milk protein yield by $7.5 \%(P=0.06)$ and content by $5.7 \%(P=0.09)$ similarly at both levels of
PDIE. Nitrogen efficiency tended to increase by $9.0 \%$ with the $\mathrm{AA}+$ compared with $\mathrm{AA}$ - treatments $(P=$ 0.08 ) even though the AA - treatments provided similar $\mathrm{N}$ as $\mathrm{AA}+$ treatments through a duodenal infusion of urea (Table 2). Nevertheless, the PDIE efficiencies also tended to increase by $7.4 \%(P=0.07)$ with the $\mathrm{AA}+$ compared with AA- treatments. The AA+ treatments tended to decrease the $\mathrm{NE}_{\mathrm{L}}$ balance $(P=$ $0.10)$. The lactose content decreased by $2.6 \%$ in the $\mathrm{AA}+$ compared with the AA - treatments $(P=0.03)$. Milk lactose yield, milk fat yield, and milk fat content remained unchanged with the AA treatments.

Milk yield and milk protein yield as well as milk protein content of the left udder on d 13 of each treatment were not affected by increasing the PDIE supply similar to the average production of $5 \mathrm{~d}$ (contrast PDIE). The NPN content in percentage of CP increased by $13.0 \%(P=0.03)$, whereas the milk urea concentration increased by $50 \%$ in the HP compared with the LP treatments $(P=0.02)$. The AA+ treatments increased the left udder milk yield by $5.7 \%$ compared with the AA - treatments (contrast AA: $P=0.04$ ). Similarly, the AA + treatments increased milk protein yield by $10.7 \%(P=0.01)$ and milk protein content by $5.1 \%(P$ $=0.05)$ compared with the AA - treatments. The CP content of milk tended to increase by $4.4 \%(P=0.08)$, NPN in percentage of $\mathrm{CP}$ decreased by $12.7 \%(P=$ $0.03)$, whereas the milk urea concentration tended to decrease by $30 \%(P=0.07)$ in the $\mathrm{AA}+$ compared with the $\mathrm{AA}$ - treatments.

\section{Plasma Arterial Concentration}

The arterial concentration of urea (Table 5) increased $(+52 \%)$ with the increase in PDIE supply (contrast PDIE: $P=0.03)$. It tended to decrease $(-22 \%)$ with $\mathrm{AA}+$ compared with AA - treatments (contrast AA: $P=0.08)$, but urea was introduced in the duodenum in $\mathrm{AA}$ - treatments to be iso- $\mathrm{N}$ with $\mathrm{AA}+$ treatments.

Increasing the PDIE supply increased the arterial concentration of Trp (Table 5; contrast PDIE: $P=0.04$ ). In contrast, increasing the PDIE supply decreased the arterial concentration of Gly and tended to decrease the arterial concentration of Ser $(P=0.08)$. Among the EAA, a tendency to increase was observed for Arg, Ile, Leu, and Val with increasing PDIE supply $(P<0.10)$. Cumulatively, HP treatments tended to increase the arterial plasma concentration of EAA-N (summed on $\mathrm{N}$ basis, in $\mu \mathrm{mol} / \mathrm{L}$ of $\mathrm{N} ; P=0.09$ ) compared with $\mathrm{LP}$ treatments. The AA+ treatments increased the arterial concentration of His, Leu, Lys, Met, Phe, Trp, and Val (contrast AA: $P<0.05)$, tended to increase $\operatorname{Arg}(P=$ $0.07)$, and decreased $\operatorname{Thr}(P=0.07)$ compared with 
Table 4. Dry matter intake, milk yield, and milk composition of last $5 \mathrm{~d}$ and left-half udder during the evening milking of $\mathrm{d} 13$

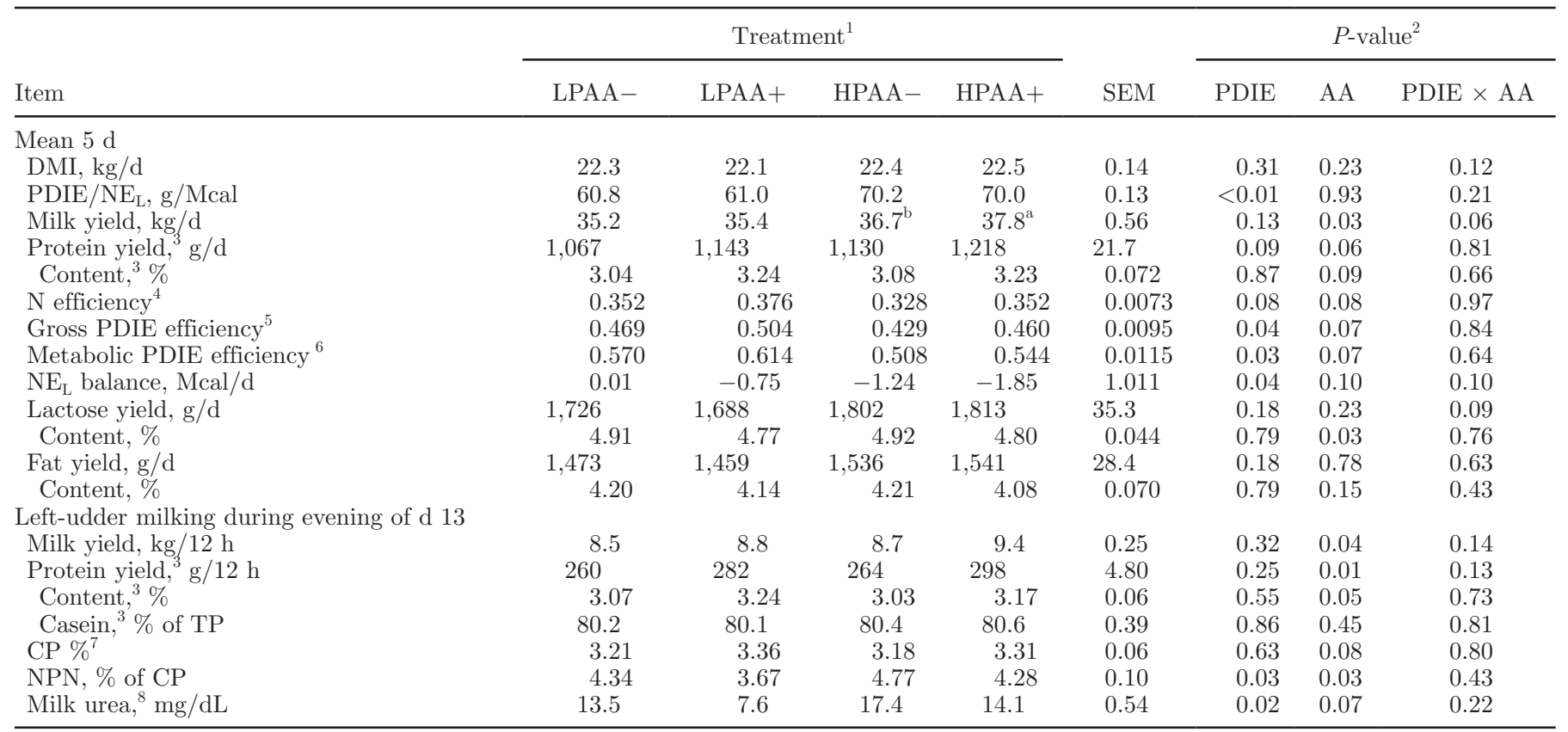

\footnotetext{
${ }^{\mathrm{a}, \mathrm{b}}$ Means with different superscripts differ at $P<0.05$ within each level of PDIE (LP or HP).

${ }^{1}$ LPAA - = low-protein diet (LP) + duodenal infusions of Glu, Pro, Ser, and urea; LPAA + = LP + duodenal infusions of Lys, Met, Leu, His, Ile, Val, Phe, Arg, Glu, and Trp; HPAA $-=$ high-protein diet (HP) + duodenal infusions of Glu, Pro, Ser, and urea; HPAA $+=$ HP + duodenal infusions of Lys, Met, Leu, His, Ile, Val, Phe, Arg, Glu, and Trp.

${ }^{2}$ Probability values correspond to the protein-supply effect: PDIE (protein digested in the small intestine supplied by RUP and by microbial protein from rumen-fermented OM; LP vs. HP); the AA-profile effect: AA (AA-vs. AA+); and the interaction between level of PDIE and AA profiles: PDIE $\times$ AA.

${ }^{3}$ True protein $(\mathrm{TP})$.

${ }^{4}$ Calculated as $\mathrm{N}$ in milk $\mathrm{CP}$ divided by $\mathrm{N}$ intake plus $\mathrm{N}$ infused in the duodenum (AA + urea).

${ }^{5}$ Gross PDIE efficiency $=$ milk protein yield $/$ PDIE intake.

${ }^{6}$ Metabolic PDIE efficiency $=$ milk protein yield/(PDIE intake - PDIE requirement for maintenance and gestation).

${ }^{7} \mathrm{CP}=$ total $\mathrm{N} \times 6.39$ in INRA $(2007)$.

${ }^{8} \mathrm{n}=15$.
}

the AA - treatments. On the other hand, the arterial concentrations of Gln, Gly, Pro, and Ser were higher in the AA - than in the AA+ treatments $(P<0.05)$. Cumulatively, the AA+ treatments increased the plasma arterial concentration of EAA-N $(P=0.03)$, of AA from group 1 (His, Met, Phe + Tyr, and Trp) and of AA from group 2 (Lys, Ile, Leu, and Val). In contrast, the $\mathrm{AA}+$ treatments similarly decreased the NEAA$\mathrm{N}(P=0.02)$ plasma arterial concentration compared with the AA - treatments at both PDIE levels (no PDIE $\times$ AA interaction).

The arterial concentration of carnosine tended to increase with increasing PDIE supply (contrast PDIE: $P$ $\leq 0.10$ ). The plasma arterial concentration of $\alpha$-amino$n$-butyric acid and $\alpha$-amino-adipic acid increased in the $\mathrm{AA}+$ compared with $\mathrm{AA}-$ treatments (contrast AA: $P$ $=0.04)$. The arterial concentration of hydroxyproline was higher in LPAA - than in LPAA+ treatment and did not change in HP treatments $(\mathrm{PDIE} \times \mathrm{AA}$ interaction). The arterial concentration of Tau was lower in HPAA - than in HPAA+ and did not change in LP treatments, leading to a PDIE $\times$ AA interaction.

\section{Mammary Plasma Flow and Half-Udder Uptake of AA}

Mammary plasma flow was not affected by any treatment (Table 6). The half-udder uptake of most AA was not affected by PDIE supply. The uptake of all EAA (Lys, Met, Leu, Ile, Val, Phe, Arg, and Thr) was higher in the $\mathrm{AA}+$ treatments than in the $\mathrm{AA}-$ treatments $(P<0.05)$ except for His and Trp $(P>0.10)$. Cumulatively (on a $\mathrm{N}$ basis), the $\mathrm{AA}+$ treatments increased the uptake of AA-N from group 1 and group 2 compared with the AA - treatments. The mammary uptake of Thr was not consistent across the different PDIE levels (PDIE $\times$ AA: $P=0.05)$ and increased only in 
Table 5. Effect of protein supply and AA profiles on plasma arterial concentrations of urea and AA

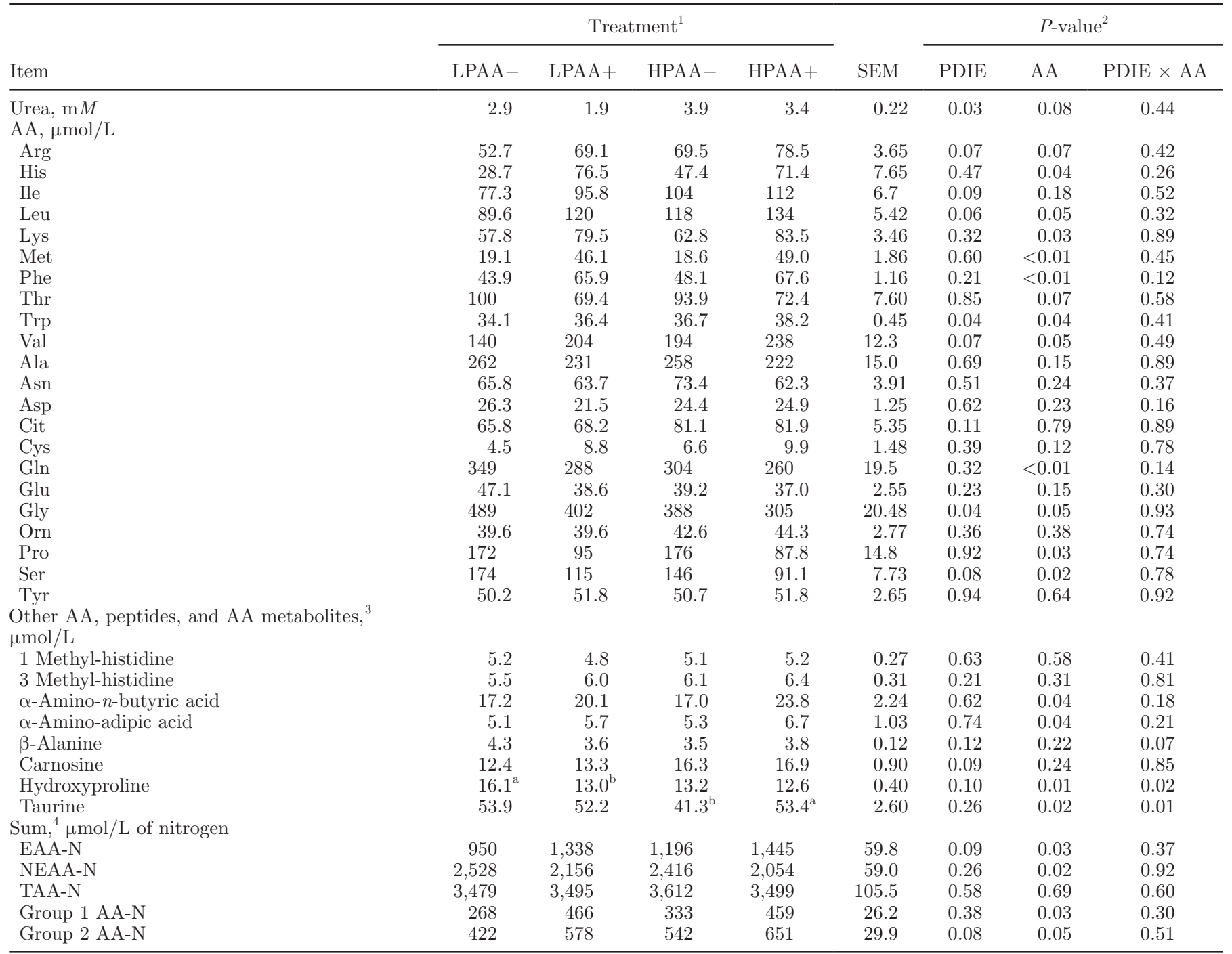

${ }^{\mathrm{a}, \mathrm{b}}$ Means with different superscripts differ at $P<0.05$ within each level of PDIE (LP or HP).

${ }^{1}$ LPAA - = low-protein diet (LP) + duodenal infusions of Glu, Pro, Ser, and urea; LPAA + = LP + duodenal infusions of Lys, Met, Leu, His, Ile, Val, Phe, Arg, Glu, and Trp; HPAA $-=$ high-protein diet (HP) + duodenal infusions of Glu, Pro, Ser, and urea; HPAA $+=$ HP + duodenal infusions of Lys, Met, Leu, His, Ile, Val, Phe, Arg, Glu, and Trp.

${ }^{2}$ Probability values correspond to the protein-supply effect: PDIE (protein digested in the small intestine supplied by RUP and by microbial protein from rumen-fermented OM; LP vs. HP); the AA-profile effect: AA (AA- vs. AA+); and the interaction between level of PDIE and AA profiles: PDIE $\times$ AA.

${ }^{3}$ Other nitrogen derivatives measured with UPLC-MS showing a plasma concentration higher than the limit of quantification. Anserine was below the limit of detection.

${ }^{4}$ EAA-N = sum on nitrogen (N) basis of Arg, His, Ile, Leu, Lys, Met, Phe, Thr, Trp, and Val; NEAA-N = sum on N basis of Ala, Asn, Asp, Cit, Cys, Gln, Glu, Gly, Orn, Pro, Ser, and Tyr; TAA-N = EAA-N + NEAA-N; Group 1 AA-N = sum on N basis on N basis of His, Met, Phe + Tyr, and Trp; Group 2 AA-N = sum on N basis of Ile, Leu, Lys, and Val.

the HPAA+ versus HPAA - treatment $(P<0.05)$. The mammary uptake of NEAA-N was not consistent across the different PDIE levels (PDIE $\times$ AA: $P=0.05$ ). The mammary uptake of TAA-N increased in HPAA+ compared with HPAA - treatment $(\mathrm{PDIE} \times \mathrm{AA}: P=$ 0.04 ) and remained unaffected in the LP treatments.
The NEAA:TAA-N uptake ratio was higher in LPAAversus LPAA + treatment but remained unchanged in the HP treatments, leading to a tendency of interaction (PDIE $\times$ AA: $P=0.09$ ). For individual NEAA, the mammary uptakes of Asn and Tyr increased with the AA+ treatments $(P=0.04)$. The uptake of Ala 
Table 6. Effect of protein supply and AA profiles on left-udder plasma flow and AA uptake

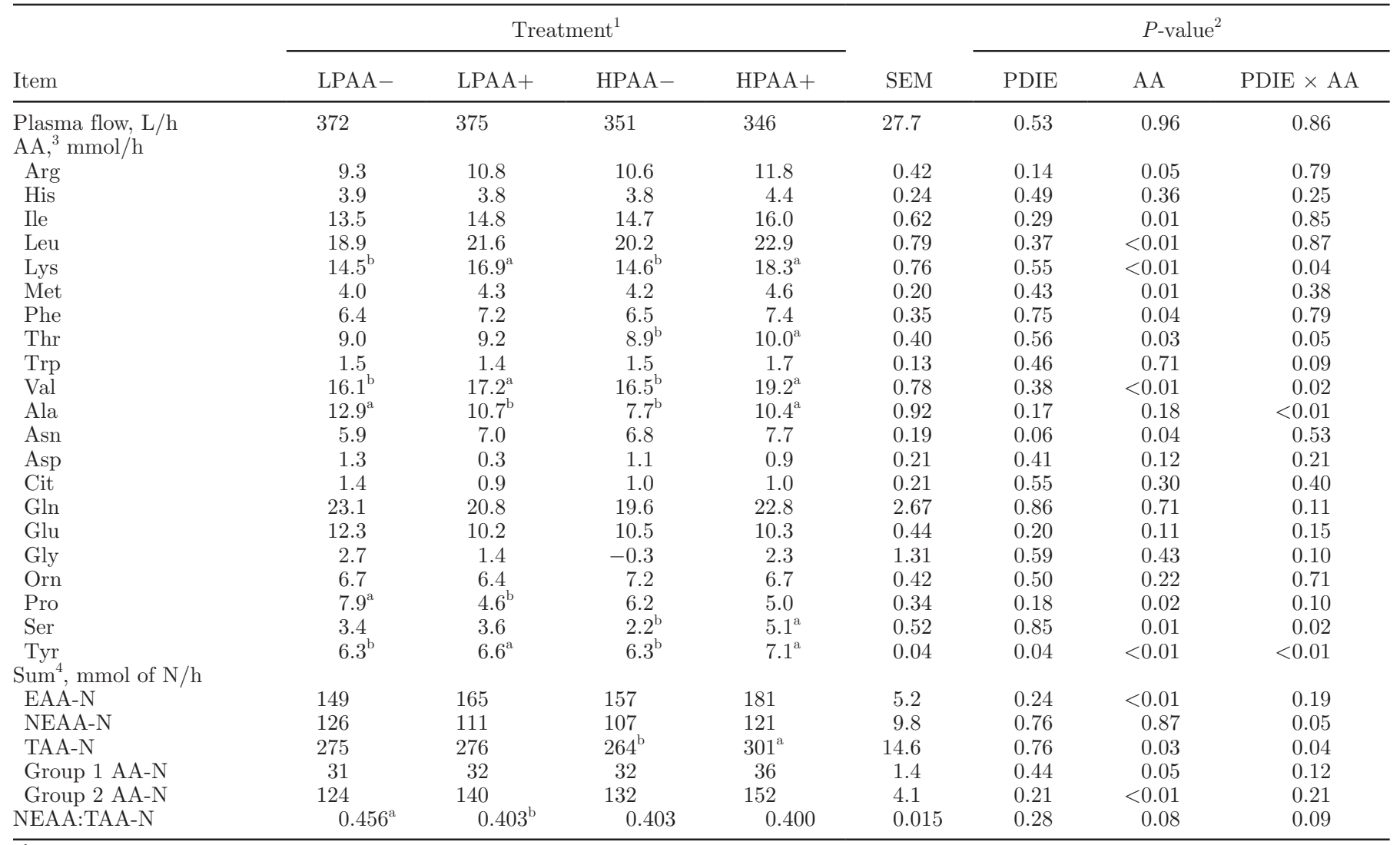

${ }_{\mathrm{a}, \mathrm{b}}$ Means with different superscripts differ at $P<0.05$ within each level of PDIE (LP or HP).

${ }^{1}$ LPAA - = low-protein diet (LP) + duodenal infusions of Glu, Pro, Ser, and urea; LPAA $+=$ LP + duodenal infusions of Lys, Met, Leu, His, Ile, Val, Phe, Arg, Glu, and Trp; HPAA - = high-protein diet (HP) + duodenal infusions of Glu, Pro, Ser, and urea; HPAA+ = HP + duodenal infusions of Lys, Met, Leu, His, Ile, Val, Phe, Arg, Glu, and Trp.

${ }^{2}$ Probability values correspond to the protein-supply effect: PDIE (protein digested in the small intestine supplied by RUP and by microbial protein from rumen-fermented OM; LP vs. HP); the AA-profile effect: AA (AA- vs. AA+); and the interaction between level of PDIE and AA profiles: PDIE $\times$ AA.

${ }^{3}$ Mammary net uptake of AA, peptides, and metabolites of AA shown in Table 5 that were not significantly different of zero were not reported in this table.

${ }^{4}$ EAA-N = sum on nitrogen $(\mathrm{N})$ basis of Arg, His, Ile, Leu, Lys, Met, Phe, Thr, Trp, and Val; NEAA-N = sum on N basis of Ala, Asn, Asp, Cit, Gln, Glu, Gly, Orn, Pro, Ser, and Tyr; TAA-N = EAA-N + NEAA-N; Group 1 AA-N = sum on N basis of His, Met, Phe + Tyr, and Trp; Group $2 \mathrm{AA}-\mathrm{N}=$ sum on $\mathrm{N}$ basis of Ile, Leu, Lys, and Val.

decreased in LPAA + versus LPAA - treatment and increased in HPAA+ versus HPAA - treatment (PDIE $\times$ AA: $P<0.01)$. The uptake of Ser was higher in $\mathrm{HPAA}+$ than in HPAA - treatment and remained unchanged in the LP treatments (PDIE $\times$ AA: $P=0.02$ ). The mammary uptake of peptide (carnosine) or AA derivatives with an arterial concentration higher than the quantification limit were not significantly different from zero.

\section{Mammary Clearance Rate of AA}

The mammary clearance rate (Table 7) of EAA-N was numerically higher (average $220 \pm 36 \mathrm{~L} / \mathrm{h}$ ) than the NEAA-N clearance rate (average $60 \pm 8 \mathrm{~L} / \mathrm{h}$ ). The mammary clearance rate of EAA-N or NEAA-N was not affected by increasing the PDIE level (contrast PDIE: $P>0.10)$. The mammary clearance rate of AA from group 2 (Lys, Ile, Leu, Val) expressed on a $\mathrm{N}$ basis tended $(P=0.08)$ to decrease in the HP versus LP treatments. The mammary clearance rate of EAA tended to be greater in LPAA - than in LPAA + treatment and remained unchanged in the HP treatments $($ PDIE $\times$ AA: $P=0.09)$. The mammary clearance rate of AA-N from group 1 decreased in the $\mathrm{AA}+$ versus AA - treatments $(P=0.04)$, and the mammary clearance rate of AA-N from group 2 tended to decrease $(P$ $=0.08)$. The NEAA-N clearance rate increased in the $\mathrm{AA}+$ treatments versus the $\mathrm{AA}$ - treatments (contrast AA: $P=0.05)$. However, this increase tended to be 
Table 7. Effect of protein supply and AA profiles on left-udder clearance rate of AA

\begin{tabular}{|c|c|c|c|c|c|c|c|c|}
\hline Clearance rate, ${ }^{1} \mathrm{~L} / \mathrm{h}$ & \multicolumn{4}{|c|}{ Treatment $^{2}$} & SEM & \multicolumn{3}{|c|}{$P$-value ${ }^{3}$} \\
\hline EAA-N & $273^{\mathrm{a}}$ & $199^{\mathrm{b}}$ & 212 & 196 & 10.5 & 0.12 & 0.01 & 0.09 \\
\hline TAA-N & 99.9 & 101.6 & 92.4 & 114.2 & 4.4 & 0.62 & 0.12 & 0.15 \\
\hline Group 1 AA-N & 174 & 87 & 133 & 101 & 13.3 & 0.42 & 0.04 & 0.50 \\
\hline Group 2 AA-N & 368 & 270 & 268 & 256 & 16.9 & 0.08 & 0.08 & 0.12 \\
\hline
\end{tabular}

${ }_{\mathrm{a}, \mathrm{b}}$ Means with different superscripts differ at $P<0.05$ within each level of PDIE (LP or HP).

${ }^{1}$ Clearance rate (Hanigan et al., 1998a) calculated as sum mammary-gland uptake (in $\mu M / \mathrm{d}$ of $\mathrm{N}$ ) divided by venous concentration (in $\mu M / \mathrm{L}$ of N). EAA-N = sum on nitrogen (N) basis of Arg, His, Ile, Leu, Lys, Met, Phe, Thr, Trp, and Val; NEAA-N = sum on N basis of Ala, Asn, Asp, Gln, Glu, Gly, Pro, Ser, and Tyr; TAA-N = EAA-N + NEAA-N; Group 1 AA-N = sum on N basis of His, Met, Phe + Tyr, and Trp; Group 2 $\mathrm{AA}-\mathrm{N}=$ sum on $\mathrm{N}$ basis of Ile, Leu, Lys, and Val.

${ }^{2}$ LPAA - = low-protein diet (LP) + duodenal infusions of Glu, Pro, Ser, and urea; LPAA + = LP + duodenal infusions of Lys, Met, Leu, His, Ile, Val, Phe, Arg, Glu, and Trp; HPAA $-=$ high-protein diet (HP) + duodenal infusions of Glu, Pro, Ser, and urea; HPAA $+=$ HP + duodenal infusions of Lys, Met, Leu, His, Ile, Val, Phe, Arg, Glu, and Trp.

${ }^{3}$ Probability values correspond to the protein-supply effect: PDIE (protein digested in the small intestine supplied by RUP and by microbial protein from rumen-fermented OM; LP vs. HP); the AA-profile effect: AA (AA- vs. AA+); and the interaction between level of PDIE and AA profiles: PDIE $\times$ AA.

different at LP and HP treatments (interaction PDIE $\times$ AA: $P=0.09)$; it increased mainly in HPAA + versus HPAA - treatment $(P<0.05)$, whereas no response was observed in LPAA+ versus LPAA - treatment.

\section{Mammary U:O Ratio}

The mammary $\mathrm{U}: \mathrm{O}$ ratio (on a $\mathrm{N}$ basis) of TAA-N was not different from one in the LPAA+, HPAA-, and HPAA+ treatments (Table 8), indicating an equilibrated mammary $\mathrm{N}$ balance for these 3 treatments; however, the ratio tended to be higher than one in LPAA - treatment, leading to a tendency for interaction between the PDIE supply level and the AA balance (Table 8; PDIE $\times$ AA: $P=0.07$ ) mainly due to a higher ratio in LPAA - than in LPAA + treatment $(P$ $<0.05)$.

The mammary U:O ratio was not different from one for Met, His, or Trp and was not affected by any treatment. The U:O ratio for Lys was not different from one in either $\mathrm{AA}$ - treatments and increased in both $\mathrm{AA}+$ treatments compared with the $\mathrm{AA}$ - treatments (contrast AA: $P=0.01$ ), whereas it decreased for Ile $(P=0.02)$. Furthermore, the response of AA was not consistent across the PDIE levels as indicated by the presence of an interaction for Lys (PDIE $\times$ AA: $P=$ $0.05)$ and tendency was observed in case of Ile $(P=$ 0.06). Cumulatively, the mammary $\mathrm{U}: \mathrm{O}$ ratio for group 1 AA-N (expressed on a $\mathrm{N}$ basis) was neither different from one nor affected by any treatment. However, for the group $2 \mathrm{AA}-\mathrm{N}$ this ratio was higher than one in all the treatments and increased in the $\mathrm{AA}+$ compared with the AA-treatments $(P=0.04)$.
For the NEAA, the mammary $\mathrm{U}: \mathrm{O}$ ratio decreased for Glu $(P=0.02)$ and Pro $(P=0.01)$ in both AA+ treatments compared with the AA - treatments, whereas the ratio increased for Ser between HPAA - and HPAA+ treatment (PDIE $\times$ AA: $P=0.05)$. Cumulatively, the changes in mammary $\mathrm{U}: \mathrm{O}$ ratio for NEAA-N (on a $\mathrm{N}$ basis) tended to be different in $\mathrm{AA}+$ versus $\mathrm{AA}-$ at LP and HP supply levels (PDIE $\times$ AA: $P=0.07$ ), and this ratio was mainly higher in LPAA - versus LPAA+ treatment $(P<0.05)$. However, this ratio was not less than one in any treatment.

\section{AA Nitrogen Partitioning}

Increasing the PDIE supply from the LP to the HP treatments increased the intestinal supply (on a $\mathrm{N}$ basis) of TAA (TAADI-N) by $16 \%$ both by increasing the EAA (EAADI-N) and the NEAA (NEAADI-N) intestinal supply (Table 9; contrast PDIE: $P<0.01$ ). Whole-udder TAA-N uptake of these AA remained unaffected $(P>0.10)$ as did left-udder uptake (Table $6)$. Consequently, the net difference between intestinal supply and whole-udder AA-N uptake in the HP treatments tended to be 33,35 , and $32 \%$ higher for TAA-N, EAA-N, and NEAA-N, respectively $(P<0.10)$. In addition, the difference for group 1 AA-N was $30 \%(P=$ 0.04) higher in the HP than in the LP treatments.

For the AA+ versus AA - treatments, the intestinal supply (on a $\mathrm{N}$ basis) of EAADI-N, group 1 AADI-N (His, Met, Phe + Tyr not Trp) and group 2 AADI-N increased by 19, 34, and 17\%, respectively. Conversely, the intestinal supply of the NEAADI-N decreased by $13 \%$ (contrast AA: $P<0.01$ ). The whole-udder uptake 
Table 8. Effect of protein supply and AA profiles on AA left-udder uptake-to-milk protein output ratio (calculated on nitrogen basis)

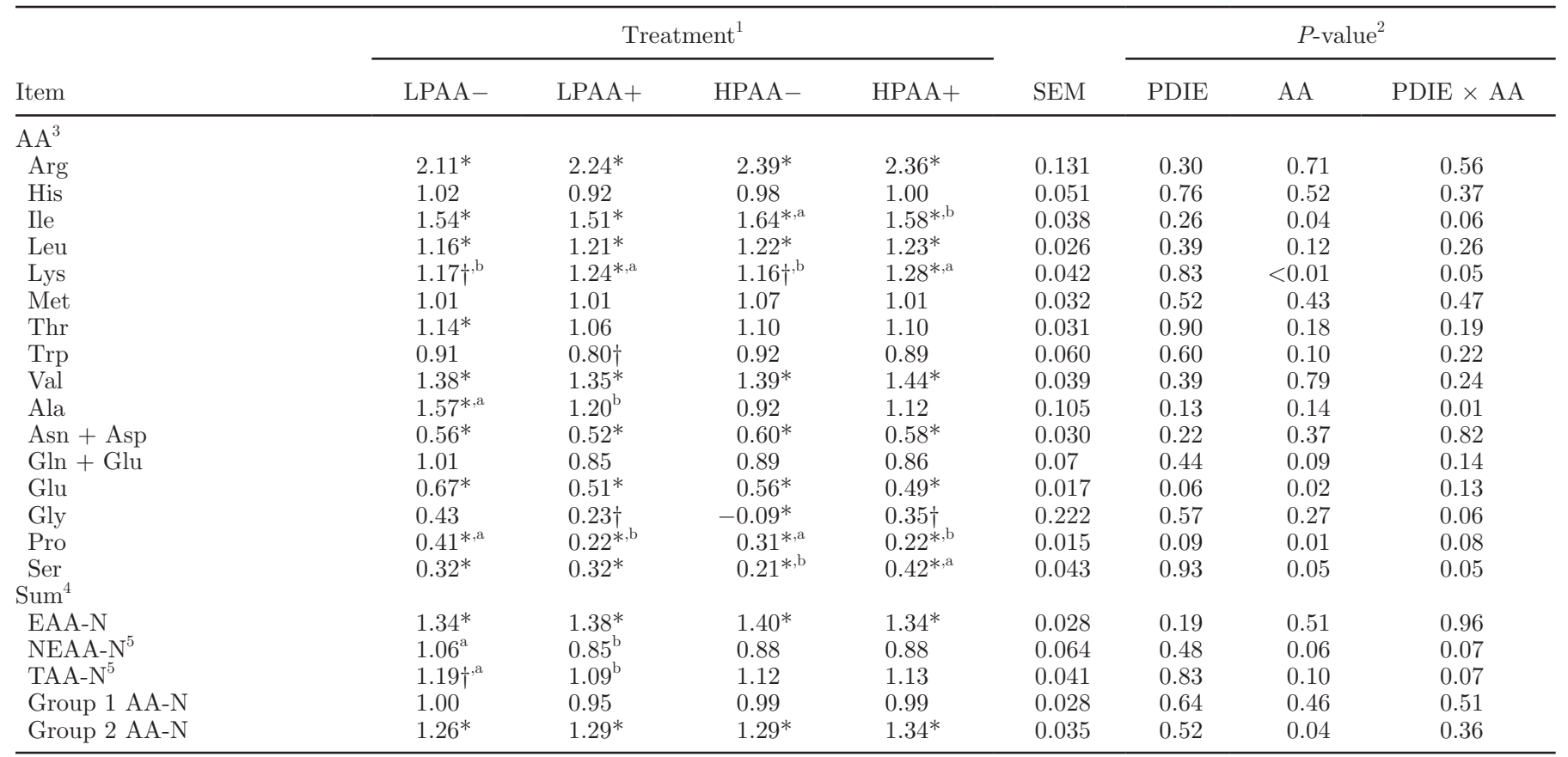

${ }^{\mathrm{a}, \mathrm{b}}$ Means with different superscripts differ at $P<0.05$ within each level of protein digested in the small intestine supplied by RUP and by microbial protein from rumen-fermented OM (PDIE; INRA, 1989; LP or HP).

${ }^{1}$ LPAA - = low-protein diet (LP) + duodenal infusions of Glu, Pro, Ser, and urea; LPAA + = LP + duodenal infusions of Lys, Met, Leu, His, Ile, Val, Phe, Arg, Glu, and Trp; HPAA - = high-protein diet (HP) + duodenal infusions of Glu, Pro, Ser, and urea; HPAA $+=$ HP + duodenal infusions of Lys, Met, Leu, His, Ile, Val, Phe, Arg, Glu, and Trp.

${ }^{2}$ Probability values correspond to the protein-supply effect: PDIE (LP vs. HP); the AA-profile effect: AA (AA- vs. AA+); and the interaction between level of PDIE and AA profiles: PDIE $\times$ AA.

${ }^{3}$ All AA presented either a net uptake or a net output different from zero.

${ }^{4}$ TAA-N = the sum on nitrogen $(\mathrm{N})$ basis of individual AA of this table; EAA-N = sum on $\mathrm{N}$ basis of Arg, His, Ile, Leu, Lys, Met, Phe, Thr, Trp, and Val; NEAA-N = sum on N basis of Ala, Asn, Asp, Gln, Glu, Gly, Pro, Ser, and Tyr; TAA-N = EAA-N + NEAA-N; Group 1 AA-N = sum on $\mathrm{N}$ basis of His, Met, Phe + Tyr, and Trp; Group 2 AA-N = sum on $\mathrm{N}$ basis of Ile, Leu, Lys, and Val.

${ }^{5}$ NEAA-N and TAA-N were calculated using our measurements of Asn + Asp and Gln + Glu in milk and the proportion of Asn:Asp and Gln:Glu in milk given by Swaisgood (1995).

*Different from one at $P \leq 0.05$; †tendency at $P \leq 0.1$.

of EAA-N increased by $10 \%(P<0.05)$ and the wholeudder NEAA-N uptake varied similarly to the left udder (Table 6). The net difference between the intestinal supply and the whole-udder EAA-N uptake increased by $40 \%$, leading to a lower proportion of intestinal EAA$\mathrm{N}$ taken up by the whole udder (i.e., EAA-N uptaketo-intestinal supply ratio). This difference between the intestinal supply and whole-udder uptake increased by $79 \%$ for group 1 AA-N and by $32 \%$ for group 2 AA-N $(P<0.05)$. Conversely, the net difference between the intestinal supply and the whole-udder uptake decreased by $22 \%$ for NEAA-N in the AA+ compared with the AA - treatments $(P=0.01)$ with a tendency of interaction (PDIE $\times$ AA: $P=0.06)$; the decrease between $\mathrm{HPAA}+$ and HPAA $-(-3.13 \mathrm{~mol} / \mathrm{d}$ of $\mathrm{N})$ was greater $(P<0.05)$ than between LPAA + and LPAA - treatments $(-0.93 \mathrm{~mol} / \mathrm{d}$ of $\mathrm{N})$. This led to a tendency of a lower proportion of NEAA intestinal supply taken up by MG (NEAA-N uptake-to-intestinal supply ratio) in $\mathrm{HPAA}-$ than in HPAA + treatment $(\mathrm{PDIE} \times \mathrm{AA}: P$ $=0.06)$.

\section{DISCUSSION}

\section{An Increase in Milk Protein Synthesis in the AA+ Treatments due to a Higher Mammary Uptake of EAA and a Variable Uptake of NEAA}

The mammary uptake of most of the EAA increased in the $\mathrm{AA}+$ compared with the $\mathrm{AA}$ - treatments, resulting in an increased milk protein yield. This result is in agreement with the literature where an increase in the EAA-N uptake of group $1 \mathrm{AA}$ and group $2 \mathrm{AA}$ (Mepham, 1982) increased milk protein yield, either through postrumen casein supply (Guinard et al., 1994a; Raggio et al., 2006) or through EAA infusions 
Table 9. Effect of protein supply and AA profiles on estimated AA nitrogen partition between whole-udder uptake and other utilization calculated on the $5 \mathrm{~d}$ of intake measurement on $18 \mathrm{AA}$

\begin{tabular}{|c|c|c|c|c|c|c|c|c|}
\hline Item,${ }^{1} \mathrm{~mol} / \mathrm{d}$ of $\mathrm{N}$ & \multicolumn{4}{|c|}{ Treatment $^{2}$} & SEM & \multicolumn{3}{|c|}{$P$-value ${ }^{3}$} \\
\hline \multicolumn{9}{|c|}{ Intestinal supply, $\mathrm{AADI}^{4}$} \\
\hline EAADI-N & 9.70 & 11.61 & 11.50 & 13.52 & 0.059 & $<0.01$ & $<0.01$ & 0.45 \\
\hline NEAADI-N & 10.95 & 9.42 & 12.52 & 10.95 & 0.054 & $<0.01$ & $<0.01$ & 0.73 \\
\hline TAADI-N & 20.65 & 21.03 & 24.02 & 24.47 & 0.067 & $<0.01$ & $<0.01$ & 0.20 \\
\hline TOT-N & 21.25 & 21.03 & 24.57 & 24.47 & 0.068 & $<0.01$ & $<0.01$ & 0.04 \\
\hline \multicolumn{9}{|l|}{ Whole-udder uptake } \\
\hline EAA-N & 7.17 & 7.90 & 7.93 & 8.68 & 0.193 & 0.11 & $<0.01$ & 0.72 \\
\hline NEAA-N & 5.14 & 4.54 & 4.43 & 4.98 & 0.387 & 0.83 & 0.85 & 0.03 \\
\hline TAA-N & 12.31 & 12.44 & 12.36 & 13.66 & 0.570 & 0.51 & 0.03 & 0.05 \\
\hline Group 1 AA-N & 1.40 & 1.44 & $1.47^{\mathrm{b}}$ & $1.58^{\mathrm{a}}$ & 0.049 & 0.26 & 0.02 & 0.08 \\
\hline \multirow{2}{*}{\multicolumn{9}{|c|}{ Intestinal supply - whole-udder uptake }} \\
\hline & & & & & & & & \\
\hline EAA-N U:I & 0.74 & 0.68 & 0.69 & 0.64 & 0.02 & 0.20 & $<0.01$ & 0.20 \\
\hline NEAA-N U:I & 0.47 & 0.48 & $0.36^{\mathrm{a}}$ & $0.45^{\mathrm{b}}$ & 0.04 & 0.29 & 0.04 & 0.06 \\
\hline
\end{tabular}

${ }_{\mathrm{a}, \mathrm{b}}$ Means with different superscripts differ at $P<0.05$ within each level of protein digested in the small intestine supplied by RUP and by microbial protein from rumen-fermented OM (PDIE; INRA, 1989; LP or HP).

${ }^{1}$ TAA-N $=$ sum on a nitrogen basis $(\mathrm{N})$ on the same 18 AA as AADI without taking into account urea infused in the duodenum; EAA-N = sum on N basis of Arg, His, Ile, Leu, Lys, Met, Phe, Thr, and Val (not Trp); NEAA-N = sum on N basis of Ala, Asp + Asn, Glu + Gln, Gly, Pro, Ser, and Tyr; Group 1 AA-N measured in AADI, that is, sum on N basis of His, Met, and Phe + Tyr not Trp; Group 2 AA = sum on N basis of Ile, Leu, Lys, and Val; TOT-N = TAADI-N plus intestinal urea; U:I = uptake:intestinal supply.

${ }^{2}$ LPAA - = low-protein diet (LP) + duodenal infusions of Glu, Pro, Ser, and urea; LPAA + = LP + duodenal infusions of Lys, Met, Leu, His, Ile, Val, Phe, Arg, Glu, and Trp; HPAA - = high-protein diet (HP) + duodenal infusions of Glu, Pro, Ser, and urea; HPAA+ = HP + duodenal infusions of Lys, Met, Leu, His, Ile, Val, Phe, Arg, Glu, and Trp.

${ }^{3}$ Probability values correspond to the protein-supply effect: PDIE (LP vs. HP); the AA-profile effect: AA (AA- vs. AA+); and the interaction between level of PDIE and AA profiles: PDIE $\times$ AA.

${ }^{4}$ AADI = AA digestible in the small intestine (DI; Rulquin et al., 1998, 2001; INRA, 2007), that is, for EAA: Arg, His, Ile, Leu, Lys, Met, Phe, Thr, and Val (not Trp) and for NEAA: Ala, Asp (+ Asn), Glu (+ Gln), Gly, Pro, Ser, and Tyr.

(Doepel and Lapierre, 2010). Moreover, the mammary $\mathrm{U}: \mathrm{O}$ ratio for the sum of the group 1 AA was not different from one in any treatment (Table 8), indicating that these AA were principally used for milk protein synthesis according to the literature (Mepham, 1982) irrespective of the quantity (PDIE) or the EAA composition of the dietary protein. Expressed another way, these results indicated that the increased uptake of AA from group 1 was an obligatory process to increase milk protein synthesis. On the other hand, the mammary $\mathrm{U}: \mathrm{O}$ ratio was higher than one for group $2 \mathrm{AA}$ as well as for Arg in all treatments, indicating their use in the MG to provide $\mathrm{N}$ for NEAA synthesis (Verbeke and Peeters, 1965; Clark, 1975; Mepham, 1982). Moreover, the mammary $\mathrm{U}: \mathrm{O}$ ratio of group $2 \mathrm{EAA}$ in this experiment increased (on a $\mathrm{N}$ basis) in the $\mathrm{AA}+$ versus the AA - treatments (Table 8). This result was consistent with the literature, in which the increased casein supply in the intestine increased the mammary $\mathrm{U}: \mathrm{O}$ ratio of the group 2 EAA (see review by Lapierre et al., 2012b).
In the present experiment, the increase in milk protein yield with $\mathrm{AA}+$ resulted from different changes in the NEAA uptake and metabolism at LP and HP levels leading to PDIE $\times$ AA interactions. In fact with LPAA + , the NEAA-N uptake decreased compared with the LPAA - treatment. A decrease in the mammary $\mathrm{U}: \mathrm{O}$ ratio of $\mathrm{NEAA}-\mathrm{N}$ in the $\mathrm{LPAA}+$ versus LPAA - treatment $($ PDIE $\times$ AA interaction) was also observed. This suggested that more NEAA were synthesized in the MG in LPAA + than in LPAA - because the mammary TAA uptake was almost equal to the milk protein output in the fraction synthesized by the MG (i.e., the TAA U:O ratio on a $\mathrm{N}$ basis was almost equilibrated in all treatments). To specify which individual AA contributed to the changes in the AA intramammary metabolism between LPAA - and other treatments is difficult because the mammary $\mathrm{U}: \mathrm{O}$ ratio of TAA-N was slightly higher than one in the LPAAtreatments. An overestimation of the TAA-N uptake in the LPAA - treatments could not be ruled out because 
the AA output concentrations in milk protein did not change among treatments and were close to those in Swaisgood (1995). The mammary U:O ratio of TAA-N was slightly higher than one in LPAA-, which might also indicate a low level of peptide production by the MG in the vein in this treatment, not accounting for the mammary TAA output. In detail, the higher contribution of the NEAA-N uptake to the NEAA-N output in milk protein in LPAA - could be explained by a greater increase in the uptake of Ala, Gly, and Pro relative to their output. Interestingly, Ala seemed to provide much $\mathrm{N}$ to other NEAA in LPAA - because its $\mathrm{U}: \mathrm{O}$ ratio was higher than one (1.57) compared with the other treatments. Important variations in the Ala $\mathrm{U}: \mathrm{O}$ ratio were also observed (from 0.5 to 2 ) depending on the nutritional situation (Raggio et al., 2006; Doepel and Lapierre, 2010).

Under HP conditions, the increase in the milk protein yield in the $\mathrm{AA}+$ versus the $\mathrm{AA}$ - treatments was explained differently than in LP $(\mathrm{PDIE} \times \mathrm{AA}$ interaction). Both the EAA and NEAA uptakes increased in HPAA + versus HPAA - treatment, with no major change in MG metabolism because the NEAA-N mammary U:O ratio was not further decreased in HPAA+ than in HPAA - and LPAA+. This result is consistent with the study by Doepel and Lapierre (2010), where increasing the EAA:TAA supply ratio showed an interaction between the NEAA uptake and the TAA supply. Moreover, increasing the $\mathrm{NE}_{\mathrm{L}}$ supply via postruminal glucose or ruminal propionic acid has been shown to increase both the group 1 AA uptake and the NEAA (Raggio et al., 2006; Lemosquet et al., 2010). However, in the present experiment the uptakes of NEAA and AA from group 1 and group 2 increased in HPAA+ versus HPAA - (PDIE $\times$ AA interaction), whereas the $\mathrm{NE}_{\mathrm{L}}$ supply was limited relative to the TAA supply (or the PDIE supply, Vérité and Delaby, 2000; INRA, 2007) and the $\mathrm{NE}_{\mathrm{L}}$ balance was negative in the HP treatments. Interestingly, this increase in the NEAA uptake cannot be related to the total NEAA intestinal supply that actually decreased from HPAA - to HPAA + in this study (Table 3). A possible explanation is an increase in the mammary clearance rate of the total NEAA-N in the HPAA+ versus HPAA - treatment (Table 7), whereas the mammary NEAA-N clearance rate did not vary in the LPAA+ versus LPAA - treatment. All this indicates that in the present experiment in agreement with other experiments (Raggio et al., 2006; Doepel and Lapierre, 2010), increasing the EAA supply increased the milk protein yield; however, the mammary NEAA uptake was altered to both the mammary EAA uptake and the MG metabolism of EAA from group 2 to increase milk protein synthesis.

\section{Efficiency of AA Utilization in Relation to AA Profile and Energy Supply}

The PDIE efficiency tended to increase in the AA+ compared with the AA - treatments due to a higher milk protein yield, despite the fact that both the AA+ and AA - treatments provided a similar amount of intestinal AA within each PDIE level. Contrarily, the PDIE efficiency decreased with increasing PDIE supply because neither the mammary uptake of AA nor the milk protein yield varied. This indicates that modifying the AA profile can increase the PDIE efficiency. In the present experiment, the $\mathrm{AA}+$ treatments increased the proportion of the EAA supply to the PDIE (TAA) supply (from 40 to $48 \%$, Table 3) similarly at both PDIE levels. Moreover, several results indicated that the EAA supply was low relative to the capability of the MG for milk protein synthesis and the $\mathrm{NE}_{\mathrm{L}}$ supply in the LPAA - treatment compared with the 3 other treatments. More precisely, a higher EAA-N clearance rate $($ PDIE $\times$ AA interaction, Table 7), a higher uptake of NEAA with a higher NEAA:TAA uptake ratio (Table 6 ), and a higher mammary NEAA U:O ratio (1.06; Table 8) were observed in LPAA - compared with the 3 other treatments (PDIE $\times$ AA interaction). This indicated that the total EAA supply could be limiting in certain diets.

Such a MG adaptation was not observed in HPAA+ versus HPAA-. However, the possibility that a limited $\mathrm{NE}_{\mathrm{L}}$ supply in relation to the TAA supply (PDIE) in HP diets (Hanigan et al., 1998a; Vérité and Delaby, 2000) decreased the gain in the milk protein yield in HPAA + versus HPAA - treatment might not be excluded. A similar hypothesis can also be used to explain why only a trend toward an increase in the milk protein yield was observed between the HP and LP treatments in this study because the $\mathrm{NE}_{\mathrm{L}}$ balance decreased in the HP versus the LP treatments and was negative in the HP treatments. The LP treatments had a PDIE:NE $\mathrm{N}_{\mathrm{L}}$ ratio slightly lower than the INRA (2007) recommendation, whereas the PDIE: $\mathrm{NE}_{\mathrm{L}}$ ratio was above the recommended value for the HP treatments. In fact, the increase in milk protein yield between HP versus LP was similar to the increase estimated $(1.06 \%)$ by INRA (2007) and Vérité and Delaby (2000) when the PDIE:NE $E_{\mathrm{L}}$ was increased from 61 to $70 \mathrm{~g} / \mathrm{Mcal}$. Overall, in diets based on corn silage and soybean meal, the exact requirements of EAA beyond Lys and Met (Rulquin et al., 1993; Schwab, 1996) are not well defined (Doepel et al., 2004; Haque et al., 2013). Hence, to increase PDIE efficiency in lactating dairy cows, after balancing the supply of PDIE:NE $\mathrm{N}_{\mathrm{L}}$, Lys and Met, a second step could be added to increase the EAA-to-TAA ratio in 
the diet as proposed by Doepel et al. (2004) because it would increase the supply of the second limiting EAA, leading to a higher efficiency of milk protein synthesis in the MG.

The gain of efficiency in AA+ versus AA - treatments was explained by a change in the AA partitioning between mammary uptake and utilization in other tissues. First, the $\mathrm{AA}+$ and $\mathrm{AA}-$ treatments provided similar amounts of intestinal AA (Table 3). Second, the milk protein yield increased in response to the $\mathrm{AA}+$ versus $\mathrm{AA}-$ treatments, and mammary uptake of TAA-N was almost equal to the milk protein output (TAA-N U:O in Table 8) across the whole range of treatments. Accordingly, a decrease in the extramammary catabolism of AA in AA+ treatments could be possible. The estimate of the difference between the intestinal supply and whole-udder net uptake of TAA$\mathrm{N}$ (Table 9) confirmed that less intestinal AA were available for uses other than for mammary uptake in $\mathrm{HPAA}+$ than in HPAA- (PDIE $\times \mathrm{AA}$ interaction). The rest of TAA-N not used by MG did not significantly decrease in LPAA+ versus HPAA-, probably because an overestimation of the TAA-N uptake in LPAA - was observed leading to a TAA-N U:O that tended to be higher than one. The lower plasma and milk urea concentrations, as well as a lower NPN content in the milk $\mathrm{CP}$ in the $\mathrm{AA}+$ versus the $\mathrm{AA}$ - treatments, could also indicate a decrease in extramammary AA catabolism. It is possible that the plasma urea was higher in the $\mathrm{AA}$ - versus $\mathrm{AA}+$ treatments because of the urea infusion in the duodenum in AA - treatments. However, a similar decrease in plasma urea and an increase in $\mathrm{N}$ efficiency were observed in Haque et al. (2012), who used similar AA+ versus AA - treatments without an intestinal urea infusion.

The estimation of the difference between the intestinal AA supply and the whole-udder uptake in Table 9 was also used to identify which AA fraction could be less extensively catabolized in the $\mathrm{AA}+$ versus $\mathrm{AA}$ - treatments. In fact, the difference between the intestinal supply of NEAA-N and its uptake was both decreased in LPAA + versus LPAA $-(-0.93 \mathrm{~mol} / \mathrm{d}$ of $\mathrm{N}$; Table 9) and in HPAA+ versus HPAA- $(-2.13$ $\mathrm{mol} / \mathrm{d}$ of $\mathrm{N}$ ), suggesting that a lower amount of NEAA could be available for catabolism in tissues other than the MG. This decrease was explained because the NEAA-N supply was decreased in the AA+ treatments compared with the AA - treatments $(-1.53 \mathrm{~mol} / \mathrm{d}$ of $\mathrm{N}$ from NEAA; Table 9), whereas the NEAA-N uptake either slightly decreased $(-0.60 \mathrm{~mol} / \mathrm{d}$ of $\mathrm{N})$ in LPAA + versus LPAA - or increased $(+0.55 \mathrm{~mol} / \mathrm{d}$ of $\mathrm{N})$ in the HPAA+ versus HPAA - treatment. A numerical comparison of HPAA - and LPAA + treatments offers a better understanding of the positive effect of reducing the NEAA intestinal supply on the gain in $\mathrm{N}$ efficiency. Interestingly, the milk protein yield was similar in the HPAA - versus LPAA + treatment, as previously observed by Bach et al. (2000). In fact, the HPAA - versus LPAA + treatment was designed in such a way that the intestinal supply of EAA remained similar, that is, 11.5 versus $11.6 \mathrm{~mol} / \mathrm{d}$ of $\mathrm{N}$ from AA, respectively (Table 3), whereas the NEAA supplies provided 12.5 versus $9.4 \mathrm{~mol} / \mathrm{d}$ of $\mathrm{N}$, respectively (Table 9). Despite these variations in intestinal NEAA supply, the whole-udder EAA uptake $(7.9 \mathrm{~mol} / \mathrm{d}$ of N, Table 9$)$ and NEAA uptake ( 4.5 and $4.4 \mathrm{~mol} / \mathrm{d}$ of $\mathrm{N}$ ) and the $\mathrm{U}: \mathrm{O}$ ratio $(\mathrm{AA} N)$ were similar in the LPAA+ versus HPAA - treatment. A higher intestinal NEAA supply was not used by the whole udder $(8.1$ vs. $4.9 \mathrm{~mol} / \mathrm{d}$ of N) in HPAA - compared with the LPAA + treatment. Overall in the AA+ treatments, a higher PDIE efficiency was observed because an increase of the EAA uptake stimulated milk protein synthesis in accordance with Doepel et al. (2004). As in the AA+ versus AAtreatments in which the NEAA-N intestinal supply decreased, the increase in the milk protein yield favored the partitioning of the NEAA-N toward the MG. This led to a similar proportion of intestinal NEAA-N taken up by the MG in LPAA+ and LPAA - (0.48; Table 9) and to a higher proportion of intestinal NEAA-N taken up in HPAA + than in HPAA - (0.45 vs. 0.36).

In the $\mathrm{AA}+$ versus $\mathrm{AA}$ - treatments, the mammary EAA uptake did not increase as much $(0.74 \mathrm{~mol} / \mathrm{d}$ of $\mathrm{N}$; Table 9) as the intestinal EAA supply increased (1.97 mol of N/d; Table 9), which leads to a higher amount of the EAA-N left unused by MG $(+1.22 \mathrm{~mol} / \mathrm{d}$ of $\mathrm{N}$ from EAA; Table $9 ; P<0.01)$. A lower proportion of the EAA-N supply was then used by the MG in the AA+ treatments (0.66) versus AA - treatments $(0.715 ; P<$ $0.01)$ probably because the mammary clearance rate of EAA-N decreased. This indicated an increased waste of intestinal EAA-N in the AA+ treatments and raised the question of the relevance of the ideal EAA profile used in this study.

\section{Intestinal Supply and AA Requirements to Improve PDIE Efficiency}

Designing an ideal AA profile for dairy cows is a challenging task because the concept of the single limiting AA is questioned by recent in vitro studies showing that several EAA can independently or additively stimulate mammary protein synthesis through signaling pathways (Toerien et al., 2010; Arriola Apelo et al., 2014; Nan et al., 2014). Nevertheless, the present experiment provided information about MG functioning in response to a variable amount of EAA supply and to 2 EAA profiles. The increase in total EAA-N 
supply in $\mathrm{AA}+$ versus $\mathrm{AA}-(+19 \%$ on $\mathrm{N}$ basis $)$ was close to the increase in HP versus LP $(+16 \%$ on $\mathrm{N}$ basis); however, only the AA+ treatments increased milk protein yield, showing the importance of balancing EAA on an ideal AA profile concept. Similarly, the total intestinal supply of EAA-N (Table 9) was similar in the LPAA+ versus HPAA - treatment, but the intestinal supply of individual EAA and NEAA were quite different (Table 3). Despite these differences in intestinal supply of individual AA, MG took up similar amounts of each individual EAA (except Lys, Table 6) and of each NEAA (except Ala and Tyr) in LPAA+ and HPAA - to produce a same amount of milk protein yield.

In the present experiment, the intestinal supplies of Lys, Met, His, and Phe increased more in the AA+ versus $\mathrm{AA}-$ treatments $(+42,+22,+53,30 \%$, respectively, Table 3) compared with the HP versus LP treatments $(15,17,18$, and $18 \%$, respectively). These changes in the individual EAA supply also confirmed the importance of increasing the proportion of Met and Lys among the EAA to increase milk protein yield. The mammary Lys U:O ratio close to one indicated that Lys was mainly used for milk protein synthesis in AA - treatments, similar to the observation by Guinard and Rulquin (1994b), whereas the U:O ratio was only slightly higher than one in AA+ treatments, contrary to the review by Lapierre et al. (2012b). This was mainly due to a low supply of Lys in AA+ treatments, that is, $7.0 \%$ of the PDIE compared with the targeted $7.3 \%$ of the PDIE (the INRA requirement), indicating that the MG is sensitive to such a small variation. However, the His concentration in AA + treatments (3.0\% of PDIE) seems to be higher than the MG requirement for milk protein synthesis. In fact, His uptake did not significantly increase in the AA+ versus AA- treatments. In addition, the His not used by the MG contributed 35 to $40 \%$ of the total $\mathrm{N}$ by all intestinal EAA that was not taken up by MG in the $\mathrm{AA}+$ versus $\mathrm{AA}$ - treatments. Moreover, His metabolites such as carnosine, 1-methyl histidine, or 3-methyl histidine were not taken up by the MG in any treatment despite arterial concentrations greater than zero (except for anserine, which was below the limit of detection). This observation questions the possible contribution of endogenous His metabolites (as proposed by Lapierre et al., 2012b) to mammary uptake. The recommended allowances of HisDI at 3.0\% of PDIE (INRA, 2007; Rulquin et al., 2007) in the $\mathrm{AA}+$ treatments was most likely too high. This was in accordance with the His recommended allowances in the literature (Fraser et al., 1991; Rohr and Lebzien, 1991; Doepel et al., 2004), which are lower (2.4-2.6\% of PDIE) than the INRA (2007) recommendations. At the opposite, the increase in milk protein synthesis in AA+ versus AA - treatments was probably not dictated by Ile, Leu, Val, and Thr because their increases in intestinal supplies $(10,16,16$, and $0 \%$, respectively, Table 3 ) were lower or similar to that for the HP versus LP treatments $(17,16,16$, and $17 \%$, respectively). However, if the Thr supply did not prevent the increase in milk protein yield in the AA+ versus AA - treatments, the Thr supply was probably too low to fully increase milk protein synthesis in the LPAA+, HPAA-, and HPAA + treatments because the Thr mammary U:O ratio was low and not different from one.

\section{CONCLUSIONS}

Balancing the EAA profile in the $\mathrm{AA}+$ treatments increased milk protein synthesis similarly at both protein supply levels. This increase was related to a higher but different uptake of all EAA by the MG. The MG altered the uptake of NEAA to promote milk protein synthesis depending on the uptake and MG metabolism of EAA. The trend toward an increase in MP efficiency by balancing the EAA profile was related to a change in AA partitioning between mammary AA utilization and catabolism because the mammary $\mathrm{N}$ balance from AA was almost equilibrated. The increase in milk protein yield was obtained without any increase in the TAA intestinal supply; consequently, a lower amount of NEAA was available for catabolism in other tissues than in the MG. Increasing the EAA-to-TAA ratio in dairy diets could be useful to improve MP efficiency, before knowing the exact requirement for each EAA. This could be the next step to improve MP efficiency proposed by the INRA feeding system after balancing both the MP and $\mathrm{NE}_{\mathrm{L}}$ supplies and the Met and Lys contents of the diet. However, several parameters, such as the slight increase in the PDIE efficiency or the mammary EAA uptake or their U:O ratio and clearance rates, indicated that the $\mathrm{AA}+$ profile used in this experiment was not the ideal AA balance for dairy cows. The ideal His intestinal concentration should be less than the amount supplemented in this experiment (3.0\% of PDIE), whereas the intestinal supplies of Lys (7.0\% of PDIE) and Thr (4.5\% of PDIE) were probably too low to maximally increase milk protein synthesis.

\section{ACKNOWLEDGMENTS}

A grant for this study was provided by the Commission of the European Communities, project FP7-KBBE-2007-1 "Rednex." The authors acknowledge Adisseo and E. Devillard (Adisseo, CERN, Commentry, France) for financially supporting the first author's research and supplying DL-Met in this experiment. The authors also acknowledge Ajinomoto for supplying low-priced 
AA for this research. Special thanks to J. L. Peyraud and C. K. Reynolds for their input and discussion to develop the research idea and to P. Faverdin and L. Delaby for their suggestions about diet formulation and experimental design. The authors gratefully thank N. Huchet, M. Texier, S. Marion, T. Le Mouel, P. Potton, $\mathrm{N}$. Mezière (INRA), and S. Compin (ADISSEO) for their great help in laboratory analyses; Vet. E. Pascal (Clinique Vétérinaire, F-35 760 Saint Grégoire, France) and R. Delagarde for animal surgeries; and D. Chevrel, A. Cozien, M. Lemarchand, J. L. Harel, and J. Y. Thibaud for technical support and animal care during the experiments.

\section{REFERENCES}

AFNOR. 1998. AFNOR XPV 18-114: Aliments des animaux. Dosage des acides aminés. Association Française de Normalisation (AFNOR), Paris, France.

Arriola Apelo, S. I., J. R. Knapp, and M. D. Hanigan. 2014. Invited review: Current representation and future trends of predicting amino acid utilization in the lactating dairy cow. J. Dairy Sci. 97:4000-4017.

Bach, A., G. B. Huntington, S. Calsamiglia, and M. D. Stern. 2000. Nitrogen metabolism of early lactation cows fed diets with two different levels of protein and different amino acid profiles. J. Dairy Sci. 83:2585-2595.

Bequette, B. J., M. D. Hanigan, A. G. Calder, C. K. Reynolds, G. E. Lobley, and J. C. MacRae. 2000. Amino acid exchange by the mammary gland of lactating goats when histidine limits milk production. J. Dairy Sci. 83:765-775.

Cant, J. P., E. J. DePeters, and R. L. Baldwin. 1993. Mammary amino acid utilization in dairy cows fed fat and its relationship to milk protein depression. J. Dairy Sci. 76:762-774.

Clark, J. H. 1975. Lactational responses to postruminal administration of proteins and amino acids. J. Dairy Sci. 58:1178-1197.

Clark, J. H., H. R. Spires, and C. L. Davis. 1978. Uptake and metabolism of nitrogen components by the lactating mammary gland. Fed. Proc. 37:1233-1238.

Doepel, L., and H. Lapierre. 2010. Changes in production and mammary metabolism of dairy cows in response to essential and nonessential amino acid infusions. J. Dairy Sci. 93:3264-3274.

Doepel, L., D. Pacheco, J. J. Kennelly, M. D. Hanigan, I. F. Lopez, and H. Lapierre. 2004. Milk protein synthesis as a function of amino acid supply. J. Dairy Sci. 87:1279-1297.

Fraser, D. L., E. R. Orskov, F. G. Whitelaw, and M. F. Franklin. 1991. Limiting amino-acids in dairy-cows given casein as the sole source of protein. Livest. Prod. Sci. 28:235-252.

Guinard, J., and H. Rulquin. 1994a. Effect of graded levels of duodenal infusions of casein on mammary uptake in lactating cows. 2. Individual amino acids. J. Dairy Sci. 77:3304-3315.

Guinard, J., and H. Rulquin. 1994b. Effects of graded amounts of duodenal infusions of lysine on the mammary uptake of major milk precursors in dairy cows. J. Dairy Sci. 77:3565-3576.

Guinard, J., and H. Rulquin. 1995. Effects of graded amounts of duodenal infusions of methionine on the mammary uptake of major milk precursors in dairy cows. J. Dairy Sci. 78:2196-2207.

Guinard-Flament, J., E. Delamaire, P. Lamberton, and J. L. Peyraud. 2007. Adaptations of mammary uptake and nutrient use to oncedaily milking and feed restriction in dairy cows. J. Dairy Sci. 90:5062-5072.

Hanigan, M. D., J. P. Cant, D. C. Weakley, and J. L. Beckett. 1998a. An evaluation of post-absorptive protein and amino acid metabolism in the lactating dairy cow. J. Dairy Sci. 81:3385-3401.

Hanigan, M. D., J. France, D. Wray-cahen, D. E. Beever, G. E. Lobley, L. Reutzel, and N. E. Smith. 1998b. Alternative models for analy- ses of liver and mammary transorgan metabolite extraction data. Br. J. Nutr. 79:63-78.

Haque, M. N., H. Rulquin, and S. Lemosquet. 2013. Milk protein responses in dairy cows to changes in post-ruminal supplies of arginine, isoleucine, and valine. J. Dairy Sci. 96:420-430.

Haque, M. N., H. Rulquin, A. Andrade, P. Faverdin, J. L. Peyraud, and S. Lemosquet. 2012. Milk protein synthesis in response to the provision of an "ideal" amino acid profile at two levels of metabolizable protein supplies in dairy cows. J. Dairy Sci. 95:5876-5887.

Hasegawa, H., Y. Shinohara, K. Akahan, and T. Hashimoto. 2005. Direct detection and evaluation of conversion of D-methionine into L-methionine in rats by stable isotope methodology. J. Nutr. 135:2001-2005.

Huhtanen, P., and A. N. Hristov. 2009. A meta-analysis of the effects of dietary protein concentration and degradability on milk protein yield and milk $\mathrm{N}$ efficiency in dairy cows. J. Dairy Sci. 92:3222-3232.

INRA. 1989. Ruminant Nutrition: Recommended Allowances and Feed Tables. INRA Ed., Paris, France.

INRA. 2007. Nutrition of Cattle, Sheep and Goats: Animal Needs-Values of Feeds. Quae Ed., Paris, France.

ISO. 2005. ISO 13903: Animal feeding stuffs-Determination of amino acids content. International Organization for Standardization (ISO), Geneva, Switzerland.

Kijora, C., H. Bergner, J. Szakacz, J. Bartelt, and K. P. Gotz. 1992. Utilization of N-15-urea in sheep after N-15-urea infusion in the small-intestine. J. Anim. Physiol. Anim. Nutr. (Berl.) 67:237-249.

Lapierre, H., J. P. Blouin, J. F. Bernier, C. K. Reynolds, P. Dubreuil, and G. E. Lobley. 2002. Effect of supply of metabolizable protein on whole body and splanchnic leucine metabolism in lactating dairy cows. J. Dairy Sci. 85:2631-2641.

Lapierre, H., G. Holtrop, A. G. Calder, J. Renaud, and G. E. Lobley. 2012a. Is D-methionine bioavailable to the dairy cow? J. Dairy Sci. 95:353-362.

Lapierre, H., G. E. Lobley, L. Doepel, G. Raggio, H. Rulquin, and S. Lemosquet. 2012b. Triennial lactation symposium: Mammary metabolism of amino acids in dairy cows. J. Anim. Sci. 90:17081721.

Lemosquet, S., J. Guinard-Flament, G. Raggio, C. Hurtaud, J. Van Milgen, and H. Lapierre. 2010. How does increasing protein supply or glucogenic nutrients modify mammary metabolism in lactating dairy cows? Pages 175-187 in Energy and Protein Metabolism and Nutrition. EAAP publication No. 127. Wageningen Acad. Publ., Wageningen, the Netherlands.

Lemosquet, S., G. Raggio, G. E. Lobley, H. Rulquin, J. Guinard-Flament, and H. Lapierre. 2009. Whole-body glucose metabolism and mammary energetic nutrient metabolism in lactating dairy cows receiving digestive infusions of casein and propionic acid. J. Dairy Sci. 92:6068-6082.

Mepham, T. B. 1982. Amino acid utilization by lactating mammary gland. J. Dairy Sci. 65:287-298.

Nan, X., D. Bu, X. Li, J. Wang, H. Wei, H. Hu, L. Zhou, and J. J. Loor. 2014. Ratio of lysine to methionine alters expression of genes involved in milk protein transcription, and translation and mTOR phosphorylation in bovine mammary cells. Physiol. Genomics $46: 268-275$.

National Research Council. 2001. Nutrient Requirements of Dairy Cattle. 7th rev. ed. Natl. Acad. Sci., Washington, DC

Raggio, G., S. Lemosquet, G. E. Lobley, H. Rulquin, and H. Lapierre. 2006. Effect of casein and propionate supply on mammary protein metabolism in lactating dairy cows. J. Dairy Sci. 89:4340-4351.

Rigout, S., S. Lemosquet, A. Bach, J. W. Blum, and H. Rulquin. 2002. Duodenal infusion of glucose decreases milk fat production glucose in grass silage-fed dairy cows. J. Dairy Sci. 85:2541-2550.

Rohr, K., and P. Lebzien. 1991. Present knowledge of amino acid requirements for maintenance and production. Pages 127-137 in Proc. 6th Int. Symp. Protein Metab. Nutr. EAAP publication No. 59. Wageningen Acad. Publ., Wageningen, the Netherlands.

Rulquin, H., J. Guinard, and R. Vérité. 1998. Variation of amino acid content in the small intestine digesta of cattle: development of a prediction model. Livest. Prod. Sci. 53:1-13. 
Rulquin, H., P. M. Pisulewski, R. Vérité, and J. Guinard. 1993. Milk production and composition as a function of post-ruminal lysine and methionine supply-A nutrient-response approach. Livest. Prod. Sci. 37:69-90.

Rulquin, H., G. Raggio, H. Lapierre, and S. Lemosquet. 2007. Relationship between intestinal supply of essential amino acids and their mammary metabolism in the lactating dairy cow. Pages 587-588 in Energy and Protein Metabolism and Nutrition. EAAP publication No. 124. Wageningen Acad. Publ., Wageningen, the Netherlands.

Rulquin, H., R. Vérité, and J. Guinard-Flament. 2001. Amino acids truly digestible in the small intestine: The AADI system for the dairy cow. Prod. Anim. 14:265-274.

SAS Institute Inc. 2004. SAS System for Mixed Models. SAS Institute Inc., Cary, NC.

Schwab, C. G. 1996. Amino acid nutrition of the dairy cow: Current status. Pages 184-198 in Proc. Cornell Nutr. Conf., Ithaca, NY. College of Agriculture and Life Sciences, Cornell University, Ithaca, NY.
Steel, R. G. D., and J. H. Torrie. 1980. Principles and Procedures of Statistics: A Biometrical Approach. 2nd ed. McGraw-Hill Book Co., New York, NY.

Swaisgood, H. E. 1995. Protein and amino acid composition of bovine milk. Pages 464-471 in Handbook of Milk Composition. R. G. Jensen, ed. Acad. Press, San Diego, CA.

Toerien, C. A., D. R. Trout, and J. P. Cant. 2010. Nutritional stimulation of milk protein yield of cows is associated with changes in phosphorylation of mammary eukaryotic initiation factor 2 and ribosomal S6 kinase 1. J. Nutr. 140:285-292.

Verbeke, R., and G. Peeters. 1965. Uptake of free plasma amino acids by the lactating cow's udder and amino acid composition of udder lymph. Biochem. J. 94:183-189.

Vérité, R., and L. Delaby. 2000. Relation between nutrition, performances and nitrogen excretion in dairy cows. Ann. Zootech. 49:217-230.

Wohlt, J. E., J. H. Clark, R. G. Derrig, and C. L. Davis. 1977. Valine, leucine, and isoleucine metabolism by lactating bovine mammary tissue. J. Dairy Sci. 60:1875-1882. 